\title{
The Challenge of Spatial Information Accessibility for Agricultural Policies: Case of Pakistan
}

\begin{abstract}
Agriculture is directly linked to the socio-economic development of every region. Agriculture impacts us all, whether we are seeking food security, better health or striving to conserve natural resources. Goal 2 of Sustainable Development Goals (SDGs) underlines the significance of agriculture as a means to achieve food security. United Nations in its recently published report titled "World Economic Situation and Prospects 2020"(UN, 2020) has declared agriculture as one of the global priorities for achieving high-quality health care and formal employment opportunities. Agriculture is a spatial subject. Policy makers demand unrestricted access to spatial data of various kinds in order to address agricultural issues and for evidence-based policy-making. Therefore, what types of spatial datasets are required for agricultural policy-making is a relevant question which is the objective of this paper. This paper also explores agriculture in Pakistan, main challenges faced by the agriculture sector of the country, and how many as well as what kind of spatial datasets are required to address these policy challenges.
\end{abstract}

Keywords: Agriculture, Spatial information, Socio-economic, Challenges, Pakistan

Asmat Ali ${ }^{1}$ and Muhammad Imran ${ }^{2}$

${ }^{1}$ Corresponding-Address: Asmat Ali, PhD Student, Institute of Geoinformation \& Earth Observation, PMASARID Agriculture University, Rawalpindi, Pakistan Email: asmatali@yahoo.com

${ }^{2}$ Corresponding-Address: Muhammad Imran, Institute of Geoinformation \& Earth Observation, PMAS-ARID Agriculture University, Rawalpindi, Pakistan. Email: imran.igeo@uaar.edu.pk 


\section{Introduction}

Agriculture refers to the set of process and activities consisting in cultivating soils, producing crops and rearing animals; it includes harvesting, milking, breeding animals, and keeping animals for farming purposes (INSPIRE, 2013). The agricultural system in the world is facing tremendous pressure due to rising population, urbanization, climate change and environmental stresses(Ghosh, 2019; Zhai et al., 2020). The Pakistan Vision 2025 (Government of Pakistan, 2014) strategy also notes, "The combination of increasing global population, changing consumption patterns, stagnant agricultural technology, finite cropland, and growing water stress in the most populous areas has raised the spectre of famines and persistent food scarcity" (p.17). The Food and Agriculture Organization (FAO) of the United Nations has estimated that food production will have to be increased by at least 60 per cent to meet the needs of the world's expected population of 9 billion by 2050 (FAO, 2014a). This is a great challenge for global agriculture as one in eight people currently face food insecurity. This is the reason, agriculture is a global priority because it has direct relationship to economics as finds (Gardner, 1978; Y. Liu et al., 2020; Mihai, Florin \& Latu, 2020). Kamilaris, Assumpcio, Blasi, Torrellas, \& Prenafeta-Boldú (2018) also argue for the same, "The central role of the agricultural sector is to provide adequate and good-quality food to an increasing human population and, because of its importance and relevance, it is on the focus of the global policy agendas". United Nations in its various reports and findings has underlined the need to invest in agriculture sector not only for achieving food security and better health care as well as economics but also to provide employment opportunities to the quickly growing population of the world.

\section{Agriculture in Pakistan}

Pakistan is an agricultural country. It has an area of $796096 \mathrm{~km}^{2}$ and population of 204.65 million(Government of Pakistan, 2020). Agriculture in Pakistan consists of a vast spread of crops, livestock, fisheries, rangelands, and forestry(I. Khan \& Khan, 2018). The country has four provinces namely Punjab, Sindh, Khyber Pakhtunkhwa (KPK) and Balochistan. Punjab is the agricultural heartland of Pakistan, accounting for $73 \%$ of the total cropped area of the country whereas Sindh province account for the second largest cropped area (14\%) of the country followed by KPK (7\%) and Balochistan (5\%)(Zulfiqar \& Thapa, 2017). Pakistan is the sixth most populated country in the world and agriculture is the backbone of its economy(Ali \& Erenstein, 2017; Government of Pakistan, 2016, 2018b, 2015; M, 2016; A. Ullah et al., 2020). Pakistan has huge potential to enhance economic contribution of agriculture sector through improved productivity(Government of Pakistan, 2019a). The growth or decline of the agriculture sector directly affects other sector like service sector as notes (Government of Pakistan, 2019a), "Services [sector] growth was adversely affected by the slowdown in agriculture"(p.6). Agriculture in Pakistan is not only a source for providing food, feed and fiber but also contributes to growth as a source of raw materials for industry, and therefore also plays a vital role in Pakistan's exports earnings.

\subsection{Sustainable Development Goals}

In January 2016, the United Nations General Assembly launched 17 Sustainable Development Goals (SDGs) which are intended to be achieved by the year 2030. In collection of the 17 SDGs, Goal 1. End poverty in all its forms everywhere, Goal 2. End hunger, achieve food security and improved nutrition and promote sustainable agriculture, Goal 3. Ensure healthy lives and promote well-being for all at all ages, Goal 8. Promote sustained, inclusive and sustainable economic growth, full and productive employment and decent work for all, Goal 10. Reduce inequality within and among countries, Goal 13. Take urgent action to combat climate change and its impacts and Goal 15. Protect, restore and promote sustainable use of 
terrestrial ecosystems, sustainably manage forests, combat desertification, and halt and reverse land degradation and halt biodiversity loss are directly or indirectly related to agriculture.

On 16th February 2016, the Parliament of Pakistan unanimously approved the 17 Sustainable Development Goals (SDGs) as the national development agenda(Government of Pakistan, 2019a). On one hand, there are many synergies among SDGs, and they are mutually supportive, such as poverty eradication (Goal 1) and hunger eradication (Goal 2) as points out the report (United Nations, 2019). "On the other hand, the 2030 Agenda also implies tradeoffs, e.g. between employment generation and rising productivity (both targets of Goal 8) and between construction of physical infrastructure (Goal 9) and preserving people's settlements (Goal 11)" (Basnett \& Bhattacharya, 2015). Countries therefore has to prioritize among SDGs, due to the limited resources and national circumstances (Donoghue \& Khan, 2019). Government of Pakistan has prioritized for achieving SDGs, and has taken certain steps including data portal development that is being tested before its launch (Government of Pakistan, 2019a). Agriculture sector can facilitate in achieving objectives of SDGs 1, 2, 5, 6, $8,13,16$, and 17(Government of Punjab, 2018). The important role of agriculture in achieving the SDGs is described in Table 1.

Table 1: Role of agriculture in achieving SDGs

\begin{tabular}{l} 
Sustainable Development Goal \\
\hline Goal 1. End poverty in all its forms \\
everywhere.
\end{tabular}

Importance of Agriculture

everywhere.

Agriculture is important for ensuring food security and reducing poverty(Ali \& Erenstein, 2017).

Agricultural progress is a potent force in reducing poverty (OECD \& Brooks, 2012). Agriculture remains in general two to three times more effective at reducing poverty than an equivalent amount of growth generated in other sectors (Christiaensen et al., 2011).

Goal 2. End hunger, achieve food security and improved nutrition and promote sustainable agriculture.

Goal 3. Ensure healthy lives and promote well-being for all at all ages.

Goal 8. Promote sustained, inclusive and sustainable economic growth, full and productive employment and decent work for all.

The central role of the agricultural sector is to provide adequate and good-quality food to an increasing human population and, because of its importance and relevance, it is on the focus of the global policy agendas(Kamilaris et al., 2018).

Rapid access to [agricultural] data and information is crucial to the economic, environmental, and social well-being of our global society(National Research Council, 1993).

Without agriculture, it is impossible to live a healthy live as agriculture is the means to provide food for living a healthy life.

With more than two-thirds of the world's poor living in rural areas, higher rural incomes are a prerequisite for sustained poverty reduction and reduced hunger (OECD \& Brooks, 2012).

Goal 10. Reduce inequality within and among countries.

Goal 13. Take urgent action to combat climate change and its impacts.

Agriculture can help to reduce economic inequality among countries.

The effects of climate change can be observed across regions. In Europe, for example, heat waves have become more frequent and intense. This has caused extensive damage in agriculture and forests to the point that some forest areas are on the brink of 


\begin{tabular}{ll}
\hline Sustainable Development Goal & Importance of Agriculture \\
\hline & $\begin{array}{l}\text { collapse (UN, 2020) } \\
\text { Climate affects agriculture. The role of agriculture is } \\
\text { not only crucial in mitigating, but also in adapting to } \\
\text { climate change (FAO, 2019). }\end{array}$ \\
$\begin{array}{l}\text { Goal 15. Protect, restore and promote } \\
\text { Intense heatwaves and dry spells are likely to cause } \\
\text { sustainable use of terrestrial } \\
\text { ecosystems, sustainably manage } \\
\text { forests, combat desertification, and } \\
\text { halt and reverse land degradation and } \\
\text { halt biodiversity loss. }\end{array}$ & \\
\hline
\end{tabular}

As shown in Table 1, it can be concluded that for achieving all SGDs in general and specifically the SDGs mentioned above agriculture sector can play a pivotal role as finds Mihai, Florin \& Latu (2020), "To achieve all range of SGDs across the globe, proper attention must be paid to rural development perspectives such as quality of life improvement, sustainable agriculture, rural resilience, and circular economy and reduced inequalities".

\section{Role of Agriculture in National Economy}

Agriculture is the engine of economic growth, and agricultural growth is the cornerstone of poverty reduction. Agriculture is one of the pillars of Pakistan's economy(Government of Pakistan, 2014). The agriculture sector of Pakistan contributes 18.9 percent to GDP and absorbs 42.3 percent of labor force(Government of Pakistan, 2018b). Agriculture is also an important source of foreign exchange earnings and stimulates growth in all sectors as finds (Government of Pakistan, 2019a), "Therefore, policies aiming to improve agriculture growth, improve governance in all sectors"(p.8). Agriculture is still a major source of employment and income for a vast majority of the poor in Pakistan (M. H. Khan \& Imam, 1985). Agriculture problems in Pakistan disturb the economic growth, in 1947, the contribution of agriculture towards GDP was $53 \%$ but it fell by $21 \%$ in the last year (Azam \& Shafique, 2017). The contribution of agriculture sector in the GDP of Pakistan has decreased and the sector is facing severe stagnation in productivity and declining growth(Ghazal et al., 2015; Government of Pakistan, 2014, 2019a; I. Khan \& Khan, 2018) as shown in Table 2 and Figure 1.

Table 2: Role of agriculture in national economy (\%)

(Source: Pakistan Bureau of Statistics)

\begin{tabular}{ccccc}
\hline Year & $\begin{array}{c}\text { Share in } \\
\text { GDP }\end{array}$ & Employment & Exports & Imports \\
\hline $2014-15$ & 20.9 & 43.5 & 16.8 & 18.7 \\
$2015-16$ & 19.8 & 42.3 & 16.5 & 18.7 \\
$2016-17$ & 19.5 & 42.3 & 15.5 & 17.7 \\
$2017-18$ & 18.9 & 42.3 & 17.8 & 16.0 \\
$2018-19$ & 18.5 & 38.5 & 17.1 & 17.5 \\
\hline
\end{tabular}

From Table 2, it is evident that agriculture's share in economy and employment has declined. Similarly, agriculture's share in exports and imports is not a healthy sign, too. Like rest of the world countries, there are two basic principles of agriculture in Pakistan, too. Firstly, to provide suitable quantity of food to the population, secondly provision of employment to the people connected to agriculture. It is a fact that economic progress and prosperity of a country like Pakistan depends on its agriculture. Moreover, raising living standards in poorer states would also require increasing productivity in the agricultural 
sector(OECD, 2017). Due to this reason, policy makers always try to make utmost progress in these two fields. Although Pakistan is also trying to make progress in the field of agriculture and industry, however, unfortunately a tangible speed and progress is not visible in the fields as finds (Malik et al., 2016). Pakistan is considered as the best agricultural country due to its four seasons, fertile land and canal irrigation system. Due to these features, it is one of the top list agricultural country in crops, fruits and vegetables. In the past, foreign invasions took place to fulfil their food necessities. The dilemma is, presently the region is unable to meet the food demands of millions of its residents (Fatima et al., 2014). In spite of hard work, neither there is an increase in the production nor a decrease in problems of farmers. Contrary to this, most of the agricultural countries in the world are using spatial techniques and tools such as Geographical Information Systems (GIS) and Remote Sensing (RS) to gain maximum production by investing relatively less efforts and time. Unfortunately, in Pakistan neither there is a strong agricultural policy nor Government of Pakistan (GOP) can tap the benefits by using scientific inventions in agriculture like use of GIS and RS. Although, benefiting GIS and RS for agriculture like many other countries is obviously not new in Pakistan. Most GIS and RS applications cannot be developed with single dataset. Therefore, multiple spatiotemporal datasets collected and locked by various organizations are required to be compiled that are accurate, structured and up to date, as well. This implies that sharing of the spatial datasets is crucial for developing reliable GIS applications to support policy making process for efficient decision making in the areas such as exploration and monitoring of natural resources, climate change as well as managing and mitigating natural disasters that are a constant threat to agriculture.

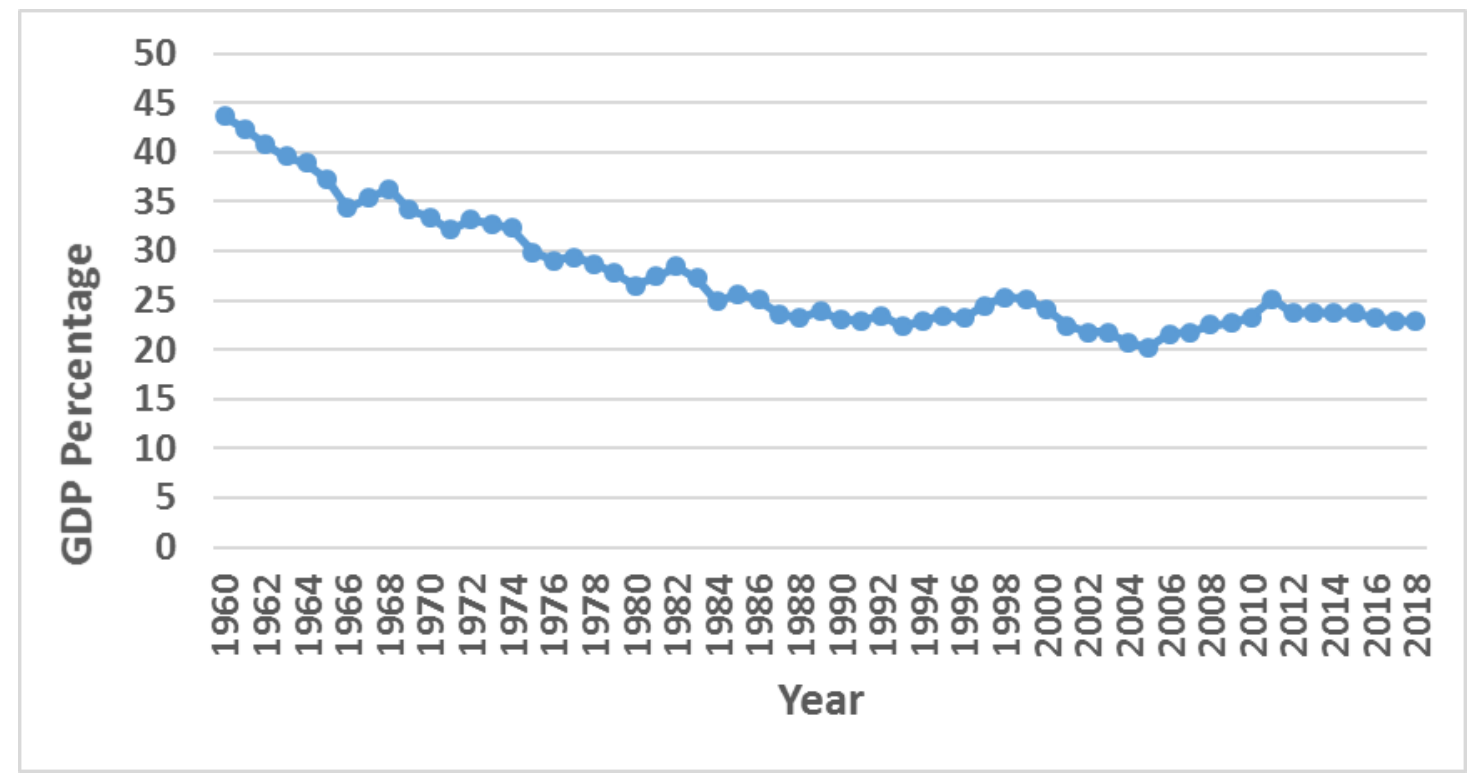

Figure 1: Declining contribution of agriculture sector in GDP (Source: World Bank)

The above scenario demand immediate attention to find out the root causes of declining agriculture in Pakistan because agriculture's declining share in GDP and employment is inevitable as economies develop(Byerlee et al., 2009; Cervantes-Godoy et al., 2008). Poor agricultural productivity can be related to the low use of improved seed, use of inappropriate fertilizer, inadequate irrigation, and lack of incentives for farmers in the absence of remunerative markets as finds Duncombe (2018). The annual plan 2019-20 (Government of Pakistan, 2019a) also aim at, "There is dire need to enhance agricultural productivity and to introduce high value crops including horticulture, livestock, poultry and fisheries to enhance income of the farmer, reduce imports and expand export base of the country" (p.ix). Large 
part of Pakistan is tropical and for such regions long-term growth policies should be reoriented to favor small farmers instead of big agribusiness players to maintain food security and social equity (Boron et al., 2016).

Since the emergence of Pakistan, the reigning governments have failed to adopt a viable mechanism for formulation and implementation of public policies (Sirajul, 2015). The task for governments is to make sure that the right policies and institutions are in place (OECD, 2010). But in case of Pakistan, politically elected government had always served their own interests rather than public issues (Sirajul, 2015). Habib (2015) suggested that for the survival, growth and stability of agricultural sector it is compulsory for every government to make an effective policy.

\section{4. key Issues to Agriculture in Pakistan}

\subsection{Review of Existing Policy Documents}

In order to identify issues to agriculture in Pakistan, first of all, existing policy documents are critically reviewed and analyzed as the policy documents are authoritative, and original information source, as well as governing tools (Macheridis, 2015). The review of existing policy documents also facilitates to understand the institutional settings and the overall policy context in a certain domain and their inter-linkage in a region. This study critically reviewed twelve relevant policy documents. The scope of these policy documents ranges from agriculture, economic development, digitization of sectorial information to climate change. The detail of policy documents reviewed is listed in Table 3.

Table 3: Policy documents reviewed for identification of issues to agriculture

- Annual Plan 2019-20

- National Food Security Policy (2018)

- National Water Policy (2018)

- Pakistan Statistical Year Book (2018)

- Pakistan Economic Survey (2018-19)

- Digital Pakistan Policy (2018)

- Pakistan Vision 2025 (2014)

- National Climate Change Policy (2012)

- National Environment Policy (2005)

- Agriculture Policy Khyber Pakhtunkhwa: A Ten-Year Perspective (2015-2025)

- Agriculture Policy of Sindh (2018)

- Punjab Agriculture Policy (2018)

Annual Plan 2019-20 (Government of Pakistan, 2019a) identify climate change, shortage of irrigation water, use of low quality inputs such as inferior seed and fertilizers, and reduction in sown area as the main issues faced by the agriculture sector of Pakistan.

National food security policy 2018 (Government of Pakistan, 2018c) highlight key issues faced by agriculture sector of Pakistan. The major issues mentioned in the policy document include, problems with the quality, quantity, and timing of supply of agricultural inputs, inefficient utilization of land and water resources, lack of infrastructure and technologies, trade restrictions, climate change effects on agriculture and livestock. And un-capitalized potential of mountain agro-ecological zones, degradation of natural resources, low priority to mainstreaming women contribution and slow rate of diffusion of technological innovations.

National water policy 2018(Government of Pakistan, 2018d) mention major challenges faced by the water sector of Pakistan such as climate change, trans-boundary water issues, 
siltation of existing dams, replacement of water storage bodies and lack of equity in water allocation at a regional levels. The issues including scarcely of fresh water resources and lack of awareness about the impending threat of water scarcity, salt imbalances in irrigated lands and the decreasing soil quality resulting in reduced yields are also stated in the policy document.

Pakistan statistical year book (2018) was reviewed. From the statistical data given in the book, it reveals that labour force working in the agriculture sector is gradually decreasing whereas temperature of the region is increasing due to climate change. The share of agriculture in GDP is also on the decline.

Pakistan economic survey 2018-19(Government of Pakistan, 2019b) attribute the underperformance of agriculture sector due to reduction in the area of cultivation, lowe water availability and drop in fertilizer off take as well as climate change. The issue of food security is also underpinned in the document.

The digital Pakistan policy(Government of Pakistan, 2018a) highlight issues including lack of agriculture information portal and integration of national as well as provincial databases in addition to duplication of efforts in data collection. The policy underscores the need to "revamp Geographical Information Systems (GIS) for Pakistan to monitor the environment and plan sustainable agriculture" (p.14). The policy underpins the preparation of agriculture related information in GIS format such as digital mapping, land use, soil types, meteorology, ecology, oceanography, hydrology and agricultural records in order to integrate national and provincial databases to avert duplication and ensure synergy (p.17).

Pakistan vision 2025(Government of Pakistan, 2014) identify, slow rate of technological innovation, limited adoption of progressive farming techniques, problems with input supply, limited investment in construction and maintenance of infrastructure. The policy also mentions trade restrictions, pest and livestock disease problems, limited amounts of credit for agricultural production and the lack of agriculture-specific financing as the major factors underlying the poor performance of the agriculture sector.

National climate change policy(Government of Pakistan, 2012) mention issues including, increased health risks, stress on water resources, migration of agriculture related population, siltation of major dams and threat to coastal areas due to projected sea level rise.

National environment policy(Government of Pakistan, 2005) highlight issues which have direct relevance for agriculture including pollution of fresh water bodies and coastal areas, air pollution, soil degradation, lack of water management, deforestation, natural disasters and climate change.

Agriculture policy of KPK(Government of Khyber Pakhtunkhwa, 2017), identify issues to agriculture in the province including climate change and natural hazards, lack of transportation infrastructure, food insecurity, increasing cost of agricultural inputs and quality concerns, shrinking financial resources, low productivity and profitability, declining water supply and land degradation, poorly managed natural resources and gender biases in agriculture. The policy also underscores post-harvest losses, inadequate agriculture research and development $(\mathrm{R} \& \mathrm{D})$ system.

Punjab agriculture policy 2018(Government of Punjab, 2018), highlight challenges faced the agriculture in the province including, lack of coherent policies, out dated agriculture produce marketing system and outdated institutional structure, climate change and poor profit for farmers. Lack of investment in human capital and diversification, depleted natural resources and low growth as well as productivity are mentioned as issues to the agriculture, too.

Agriculture policy of Sindh 2018 (Government of Sindh, 2018) mention major issues to the agriculture in the province including problems with agricultural inputs (seed, site specific fertilizer), poor infrastructure (Transport and storage), lack of institutional credit, poverty, gender biases and climate change. The issues also include malnutrition, lessening agricultural 
labor force, low yield, water availability, traditional cultivation methods, lack of food processing technology and limited quality control facilities.

\subsection{Review of Scientific Literature}

Zulfiqar \& Thapa (2017) in their study identified environmental, economic and social issues that hamper agricultural sustainability at provincial level in Pakistan. They used secondary data, covering the period of 2005/06-2012/13 for their study. Crop diversification, soil salinity, and the use of organic and inorganic fertilizers and pesticides were the indicators considered by them for environmental sustainability analysis. For economic sustainability analysis, they used, change in overall crop production and stability of crop production as indicators. Whereas employment of rural labor force and food security were used as indicators for social sustainability analysis. They find, "there are regional differences in agricultural sustainability in Pakistan". For example, they noted that inorganic fertilizer, pesticides and groundwater for irrigation are being over utilized in Sindh and Punjab. On the other hand, limited use of fertilizer and pesticides in some areas and altogether no use in other areas of KPK and Balochistan is impeding sustainable agricultural production. Moreover, they find that in the coastal areas of Balochistan, groundwater for irrigation is further reinforcing agricultural unsustainability. They recommended "to formulate effective regional agricultural policies based on local level research and revise agricultural extension structure in order to incorporate need-based services with better dissemination of information and farm level trainings".

I. A. Khan \& Khan (2018) through SWOT (Strength, Weakness, Opportunity and Threat) analysis, identified issues faced by the agriculture sector of Pakistan. The main issues identified by the authors include, land and water productivity/sustainability, climate change, stagnant yields, diversification, postharvest losses and markets, social disparity and gender, malnutrition and food security (p.5).

\section{Land and water productivity/sustainability}

Peerzado, Magsi, \& Sheikh, (2019) carried out study to explore the nexuses between urbanization and agricultural land conversion in Hyderabad, Pakistan. They find that "70 percent of agricultural land has been sold and converted in urbanization in Hyderabad district" and only 16 percent of the population is engaged in agricultural farming. According to them, reasons for selling agricultural land are, "due to certain economic, social, financial and agricultural related reasons". They highlight that this scenario can cause shortage of food in addition to issues like social, cultural, environmental and economic instability not only in the study area but also in the country.

R. Ullah, Shivakoti, Kamran, \& Zulfiqar (2019) conducted a reach study in province of Khyber Pakhtunkhwa, Pakistan. They identified that land ownership status plays important role in adaptation and mitigation of climate change threats. Farmers who own no land are the least interested in adaptation and mitigation of climate change threats. On the other hand, farmers who own land try to adopt the latest technological means to combat climatic threats.

Saltwater intrusion is also one of the problems being faced in coastal areas of Pakistan. The Indus Delta, located near Karachi is an example of seawater intrusion and land degradation due to climatic and environmental conditions(Rasul et al., 2012). Salinisation and waterlogging in the provinces of Punjab and Sindh is due to over-irrigation (Chandio et al., 2011).

I. A. Khan \& Khan (2018) argue that "subsistence-oriented farming practices, uneven distribution of ownership rights, and fragmentation" (p.6) hamper optimal utilization of land and water resource. Moreover, they find that the ground water level is declining. Accordingly, they suggest "to build new water reservoirs and the silting up of existing 
storage" (p.7). Moreover, they find that subsoil water being used for agriculture is negatively affecting soil health and organic matter content, and therefore sustainability of the entire agricultural system of the country. Aslam and Prathapar (2006) also found that major river basins such as Indus Basin in Pakistan is undergoing salinisation. In Pakistan, about 6.2 Mha of agricultural land is affected by salinity(NIAB, 1997).

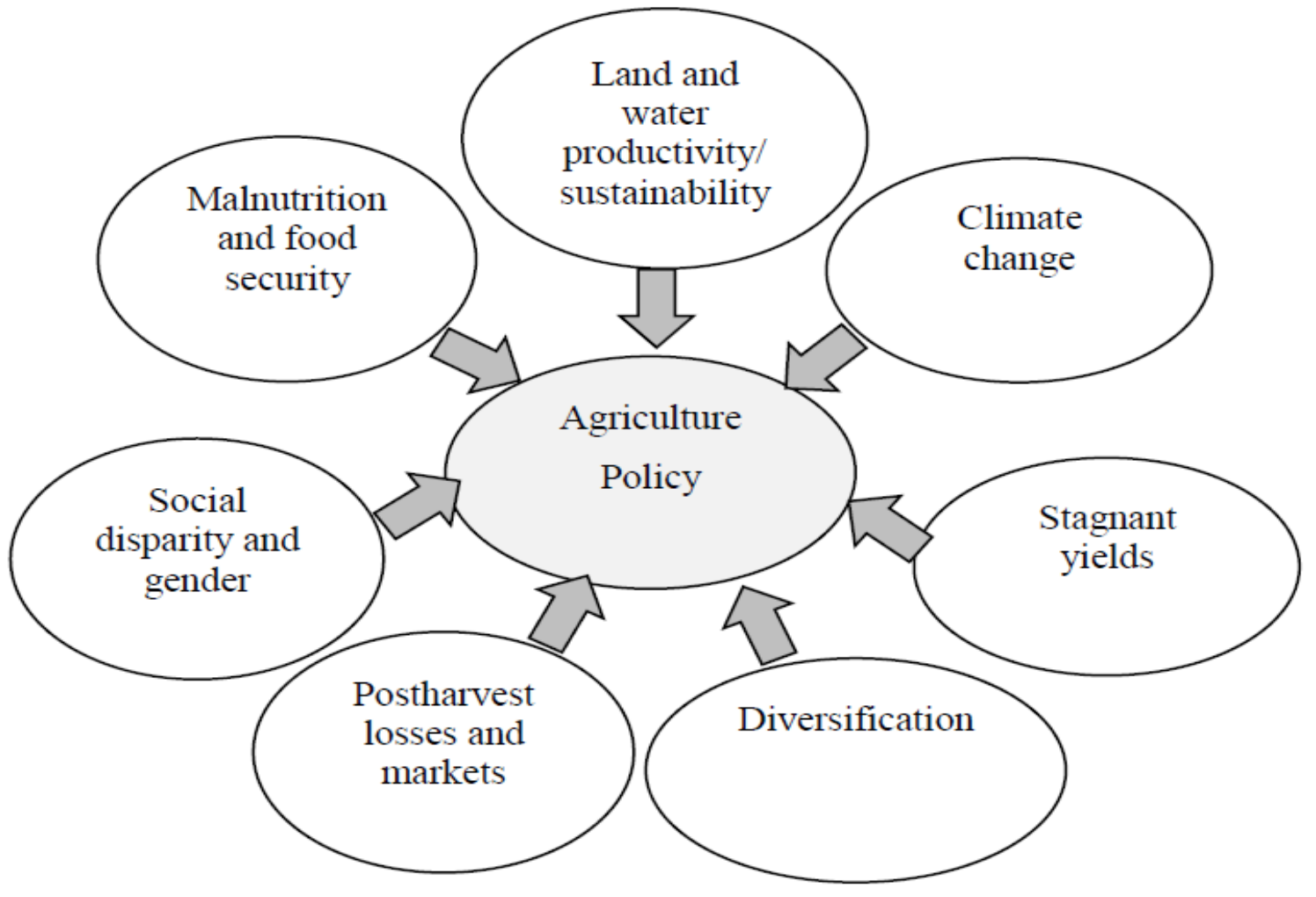

Figure 2: Important issues to agriculture policy in Pakistan Source:(I. Khan \& Khan, 2018)

Akhter \& Erenstein (2017) conducted study for assessing farmer use of climate change adaptation practices and impacts on food security and poverty in Pakistan. They find that, the majority of farms in Pakistan are small-scale with $90 \%$ of the farms being two hectares or less and "one-third of the farmers are pure tenant farmers having no land ownership". They argue that the farmer with no land ownership or having small size farms can not adapt to climate changes. However, "Farmers with large landholdings are likely to have more capacity to try out and invest in climate risk coping strategies".

It is argued that despite the fact, Pakistan owns one the best canal system in Pakistan, the sources of irrigation are scarce in the country as water is wasted in distributaries and fields due to lack of integrated water management strategy as well as system. This can also be attributed to illiteracy among farmers as most of them cannot learn new methods for irrigation such as drip irrigation. The dilemma is, large quantity of rain, fresh and river water is lost in oceans and there are no adequate measures to store this water. On the other hand, excessive load-shedding affects tube wells, and this is another setback for watering the crops. There is no specified land use system in the country and not a secure source of water, therefore farming results in low productivity (A. Ullah et al., 2020).

There is a close relationship between water resources and climate change, "Water resources are inextricably linked with climate; this is why the projected climate change has such serious implications for Pakistan's water resources"(Government of Pakistan, 2012). 


\section{Climate change}

Agriculture in Pakistan has been negatively affected by climate change(Shukla et al., 2019, p.452). Abbas et al. (2017) finds that from 1980 to 2014, there is an average shift of 4.6 days per decade earlier in the case of spring maize growing periods whereas sowing of autumn maize has been delayed 3.0 days per decade. Similarly, Tariq et al. (2018) found that due to rise in temperature from 1980 to 2016, there are shifts in sowing, emergence, anthesis, and maturity for fall and spring crops. Extreme weather condition and natural disasters negatively impact agricultural yield, food production and food security(Dizon et al., 2019).

Climate change worsens the adverse effects of weather on agriculture. Climate change has been noted as a new threat to agriculture and food security (Ahmad, Farooq, \& Umar, 2016; Gahukar, 2011). In Pakistan, India, Nepal, and China, farmers have noticed an increase in floods, landslides, drought, and disease, due to climate change(Dizon et al., 2019). These events can be attributed to a decline in the production of main crops and an increase in food insecurity (Hussain, Rasul, Mahapatra, \& Tuladhar, 2016). In Pakistan most of farmers are poor and less educated therefore they are not able to employ climate change adaptation strategies for improving agricultural yield and ultimately food security(Ahmad, Mustafa, \& Iqbal, 2016; Akhter Ali \& Erenstein, 2017). The rainfall has two-fold effects i.e. less than average rainfall or more than average both has negative effects on agricultural productivity. For example, in Pakistan, more than average rainfall is the source of floods that cause huge losses in agriculture (de Vries \& Asmat, 2016; Dorosh et al., 2010). Therefore, the food prices were high causing more food insecurity in Pakistan (Shukla et al., 2019,p.516).

R. Ullah, Shivakoti, Kamran, \& Zulfiqar (2019) find that agriculture in the region is facing several threat due to climate change and the threats are beyond the control of the local farmers. They highlighted the "significant role of land ownership status, along with perceptions of risk sources and attitude towards risk, on farmers' decisions of adopting offfarm diversification and credit reserves" to cope with climate change issues.

Srivastava (2019), provided evidence of the adverse climate change effects on agriculture, livestock production, PHM of fresh produce, food quality, and food security.

I. A. Khan \& Khan (2018) find that Pakistan is highly vulnerable to climate change affects. Accordingly, they call for disaster preparedness in order to stop potential loss of crops and livestock. The authors assert that due to improved "access to software and data gathering devices (GIS)", government should focus on developing decision support systems as it would be useful in sustainable agriculture policy formulation.

\section{Stagnant yields}

LeGouis, Oury, \& Charmet (2020) conducted study to investigate the causes of stagnation in productivity of wheat as is the case with Pakistan, too. They identified three groups of factors are; a decrease in genetic progress, resistance to change agricultural practices and unfavorable climatic conditions. They conclude that climate change is one of the main reasons causing stagnation in agricultural productivity. Liu et al. (2016) and Wiesmeier, Hübner, \& KögelKnabner (2015) also find that stagnation in productivity is largely due to climate change impacts.

I. A. Khan \& Khan (2018) highlight that "agriculture sector of Pakistan is facing severe stagnation in productivity and declining growth" (p.9). They attribute the declining growth of agriculture sector of the country to lack of interest of the farmers in their native profession, and yield gap in all the major crops such as wheat, rice, maize, cotton, and sugarcane. They compare yield with other countries of the region and world and find huge yield gaps. They find that "major reasons for this difference are unavailability of quality seed, inappropriate sowing (methods and time), weeds, lack of balanced fertilizers, partial mechanization, and excessive use of unfit irrigation water" (p.10). 


\section{Diversification}

Prăvălie (2016) finds that desertification is affecting 38 of 48 countries in Asia and it is a serious problem in Pakistan (Irshad et al., 2007; Lal, 2018). According to Ponce (2020), farmers concerns over low or no support from governments for adaptation to climate changes hamper diversification in agricultural systems which is not good for the sustainability of the system as a whole. Therefore, climate change can be considered as one of the main reasons that impede diversification in crops although "Crop diversification, as an agricultural practice, could lead to climate adaptation and mitigation" (Piedra-Bonilla et al., 2020).

R. Ullah, Shivakoti, Kamran, \& Zulfiqar (2019) in their study found that ownership status of agricultural land help to adopt crop diversification as the farmers not having their own agricultural land are forced to follow the instruction of their landlords.

Agriculture in Pakistan is dominated by five crops; wheat, cotton, rice, maize, and sugarcane (I. Khan \& Khan, 2018). They argue that the reasons for this include political economy and the interest of the farmers on food security rather than profitability. They call for giving incentives to the minor crop growers as it would help to achieve diversification.

\section{Postharvest losses (PHL) and markets}

According to Srivastava (2019), postharvest losses (PHL) can be attributed to climate change, "Climate change has a strong impact on the food industry as it affects cultivation, postharvest management (PHM), food loss, food quality, and food security". The effects the changing climate will have on post-harvest agriculture are well established and this calls for investment in PHL mitigation(Chegere, 2019).

I. A. Khan \& Khan (2018) find that due to lack of storage capacity and access to agricultural markets that includes "poor transportation, inadequate grading, very heavy spread in price between consumer and farmer, and tough competition with imported goods" (p.16) contribute to postharvest losses.

It is argued that small land holder farmers usually do not have transportation means to take their agricultural outputs to the markets and a middle man appears in most of the cases who buy their products at low price and then sell it at higher price by transporting the agricultural products to the big markets.

\section{Social disparity and gender}

The participation of women in agricultural activities can help to overcome gender barriers, enhance gender equality and food security(Shukla et al., 2019, p.70).

However, I. A. Khan \& Khan (2018) cite various statistics, to conclude that there is wide social and gender disparity in Pakistan. According to them, this impedes sustainable agriculture in the country. The existence of poor physical infrastructures including education, health facilities, safe drinking water, and sanitation in rural areas cause social disparity in the country. They argue that although rural women take part in agriculture, but "women are far less likely to own income-generating assets such as land and livestock or to have a say in household economic decisions" (p.17).

National food security policy(Government of Pakistan, 2018c) support above findings and categorically states, "Low priority to mainstreaming women contribution in value added agriculture and family nutrition". Therefore, it is evident that women are given a secondary role in decision-making in the country.

\section{Malnutrition and food security}

Agriculture is two to three times more effective at reducing poverty than other sectors (Christiaensen et al., 2011) because agriculture tends to employ more poor people(Christiaensen \& Martin, 2018; Ligon \& Sadoulet, 2018). Enhancing agricultural productivity can also improve food security(Dizon et al., 2019). However, the link between agricultural growth and food security is less clear (Kirk et al., 2018).

Research in India (for example Headey, Chiu, \& Kadiyala, 2012; Kolady, Srivastava, \& Singh, 2016; Vepa, Umashankar, Bhavani, \& Parasar, 2014) shows that states with higher 
growth in agricultural output have less food insecurity especially among children and women. Similarly, in Bangladesh, rapid growth in rice yields improved food security situation (Headey \& Hoddinott, 2016; Yu, 2012). Higher growth in agriculture can be achieved by making use of more inputs (fertilizer, seed, and the like), bringing more land under cultivation, and enhancing the productivity of inputs and agricultural land(Dizon et al., 2019).

I. A. Khan \& Khan (2018) argue that "micronutrient deficiency, known as hidden hunger, is widespread in Pakistan and well characterized among rural areas" (p.18). The issue of malnutrition and food security is relatively higher in rural areas as compared to urban centers, they conclude.

There is a direct relationship of climate change and food security as finds (Ali \& Erenstein, 2017),".... increasing weather variability and climate change have threatened the agricultural sector and thereby, have become major barriers to achieving food security and alleviating poverty in Pakistan". The climate change "threats lead to major survival concerns for Pakistan, particularly in relation to the country's water security, food security and energy security"(Government of Pakistan, 2018c).

\section{Summary of the main issues to agriculture in Pakistan}

From the review of existing policy documents and literature cited above, it reveals that main issues faced by agriculture sector of Pakistan include, climate change, low availability of water, low profitability and productivity, deprived physical infrastructure, food insecurity, quality issues, degradation of natural resources (land, water), outdated cultivation methods, issues with supply of agricultural inputs and lack of adoption of the latest technology. The most of the issues faced by the agriculture sector of Pakistan are directly or indirectly related to climate change.

\section{The Role of RS/GIS in Agriculture}

Due to large variations in climatic conditions, crops have to suffer from different types of stresses leading to reduced crop productivity and year to year variability. The conventional methods of acquiring weather and crop growth status information are reliable, but they are labour intensive and time consuming. However, recently remote sensing (RS) and geographical information system (GIS) technologies are gaining importance for acquiring spatio-temporal meteorological and crop status information for complementing the traditional methods. Under such conditions, rapidly emerging remote sensing and geospatial technology can be of great help for crop growth monitoring, identification and management of different types of stresses and regional yield estimations to sustain the natural resources and agricultural productivity. Remote sensing data can greatly contribute to the monitoring by providing timely, synoptic, cost-efficient and repetitive information about the earth's surface (Justice et al., 2002). Atzberger (2013) has illustrated five major applications of remote sensing in agriculture including biomass and yield estimation, vegetation vigor and drought stress monitoring, assessment of crop phonological development, crop acreage estimation and cropland mapping, mapping of disturbances and land use land cover changes in addition to precision agriculture and irrigation management. There was a need to develop fast track and reliable procedures to make crop forecasts and estimations early in the season or end of season. Pakistan Space and Upper Atmosphere Research Commission (SUPARCO), the Space Agency of Pakistan started developing crop area estimation procedures and crop yield models, based on the application of satellite remote sensing, GIS technology, agronomy, agrometeorology, statistics and other allied disciplines.

Korduan, Bill, and Bölling (2004) find that in agriculture, the importance of geoinformation is rising up. Agriculture is dealing with the integration of agricultural applications to the natural heterogeneity outside in the fields. They argue that using geospatial 
technologies would help in increasing yield and decreasing the means of production while the environment remains conserved. To assemble necessary information regarding spatial variability requires spatial data about the soil, the crop, the terrain, the land machinery, and the applications. For analysis, GIS should be used and that would require collection, and management of several datasets and therefore much of the time is spent in data management. Due to availability of various data capturing devices, which support different data formats, and improperly spatial reference systems one has to transform the data between proprietary GIS and coordinate systems.

Imran (2013) carried out four studies to develop services for accessing, integrating, and assessing data and models in the agriculture domain. He finds data integration problematic due to three reasons i.e. technical, conceptual and institutional. The technical reasons include various data formats and varying spatial scales. Conceptual barriers include different interpretations of the data due to lack of common standards and semantics. Whereas institutional issues such as ownership and copyrights impede data sharing. Accordingly, he recommends the use of an SDI framework for integrating and upscaling of spatial datasets in order to develop agricultural services.

Ghazal, Kazmi, \& Zubair (2015) conducted study in Pakistan for monitoring and mapping spatio-temporal dynamics of vegetation cover using Remote Sensing and GIS. They concluded, that, geospatial technologies are "ideal for mapping the extent of agricultural and other green bodies". Bordogna et al. (2016) explored integration of multisource heterogeneous geospatial data and time series in a case study for agriculture using OGC standard interoperable SDI architecture and a geospatial data and metadata workflow. They argue that geospatial information is becoming quite important not only for environmental researchers, geographers, and social scientists but also among public authorities and citizens for various purposes such as agriculture. They find that four factors play key role in favoring SDI development; legislation and new strategies, standardization activities, increasing trend of available free and open software and decreasing trend of market prices for hardware resources.

Tóth \& Kučas, (2016) find that geospatial information plays a key role in the implementation of Common Agricultural Policy (CAP) in Europe. However, agricultural decision makers have to work in order to optimize data integration for achieving transparency. They underscore the need to establish a framework for information exchange between the stakeholders. Relating information to location plays a fundamental role in agriculture. The national spatial data infrastructures (SDI) may provide valuable input for the CAP as the collected data can be shared within SDI. SDI will also contribute to the maintenance of the digital topographic databases. They highlight that data sharing will save public resources. They emphasize on standardization of geographic information in the agricultural domain.

Abdelrahman, Natarajan, and Hegde (2016) integrated RS and GIS for identification of suitable land for agriculture in Chamrajnagar, India. They identify that remote sensing (RS) data is useful for estimating biophysical parameters and indices besides cropping systems analysis, and land-use and land-cover estimations during different seasons and however, "RS data alone cannot suggest crop suitability for an area unless the data are integrated with the site-specific soil and climate data".

Sharma, Kamble, \& Gunasekaran (2018) conducted a systematic literature review (SLR) and selected 120 research articles published during 2000-2018 available in the ISI Web of Science (WoS) database on applications of GIS in agriculture. They look at GIS as a computer-based tool analytical tool which exploit spatial data. Accordingly, they mention following as GIS components, “

- Storage of spatial data in digital form.

- Management and integration of spatial data collected from different

- sources into the GIS system. 
- Retrieval and conversion of the spatial data in the required formats.

- Performing data analytics to convert data into useful information.

- Developing different models based on the information.

- Display of information model and decision making".

They find, "GIS is transforming the agriculture sector in incredible ways. The hyperspectral and multispectral images obtained through the geospatial data is found to be very useful for analyzing parameters such as crop health and soil moisture". They concluded with a call for establishing a framework for GIS data sharing, "There is a need for developing novel frameworks incorporating different layers or platforms for efficient collection of data, storage of data, data analysis and information sharing". They further discussed the need for data integration, "GIS data can be of high value to the practitioners if it is further integrated with the data collected from the other sources for deriving meaningful insights". They found that GIS data can be helpful for improved decision and policy making in agriculture such as land suitability analysis, site search selection, impact assessment, resource allocation, and developing knowledge-based systems.

Honda et al. (2014) provide evidence that farming based on detailed geospatial information increase yield and reduce the cost of fertilizers and other input resources. They implemented an agricultural information service platform and tested it on geospatial data infrastructure for crop modeling. They conclude that usage of web services from geospatial infrastructure has advantage for the agricultural information service system.

(Kliment et al., 2015) implemented a simple SDI to automate the workflows for publishing huge amount of metadata, geospatial data and remote sensing images on the Web in an interoperable and distributed way. They carried out it in a real case study to support the national agricultural sector of Italy. They found it quite handy for sharing geospatial information resources with the stakeholders.

Edeme, Nkalu, Idenyi, \& Arazu (2020) examined the positive affect of infrastructural development on agricultural output utilizing panel autoregressive distributed lag (PARDL) methodology. Physical as well as non-physical infrastructures such as ICT positively impact positively agricultural productivity, they conclude.

Policies for agriculture consist of government decisions that influence the level and stability of input and output prices, public investments affecting agricultural production, costs and revenues and allocation of resources. These policies affect agriculture either directly or indirectly. Improved agricultural production has been seen as one of the overall objectives for poverty reduction in the country. The objectives of agricultural sector strategy have been increasing agricultural growth, seen as important for increasing rural incomes and ensuring equitable distribution. Due to limited availability of high potential land, it has been envisaged that increasing agricultural production will have to come from intensification of production through increased use of improved inputs, diversification especially from low to high value crops, commercialization of smallholder agriculture, and increased value addition through stronger linkages with other sectors.

The development of the agriculture sector is therefore important for the development of the economy as a whole. In the following sections, we review some of the key policy issues and concerns with respect to the sector's development.

\section{National Food Security Policy}

The national food security policy(Government of Pakistan, 2018c) aim to:

Create a modern, efficient and diversified agricultural sector that can ensure a stable and adequate supply of basic food for the country's population, and provide high quality products to its industries for export. It ensures attractive incomes and decent employment for those who live and work in rural areas; use the resource base in an efficient and sustainable manner; 
flexibly adapt to climate change and be resilient enough to quickly recover from shocks and emergencies; and ensure that all sections of the population have stable access to adequate, nutritious and safe foods necessary for a healthy life.

Within this context, the primary function of Government of Pakistan is to act as a regulator and facilitator, creating an enabling environment that allows the dynamic subsectors, such as production of high value livestock and horticulture products for both domestic and export markets, to grow rapidly. A conducive investment environment also needs to be created in rural areas for processing, storage and value-chain development to provide employment opportunities, beyond those that can be offered by agriculture itself. At the same time more proactive policies are needed to ensure inclusive growth that will draw in vulnerable group such as small farmers, share croppers and non-agriculture workers; address resource scarcity and degradation issues particularly related to land and water; and bring about a rapid reduction in hunger and malnutrition. In line with the above, the key elements of a new agriculture policy for Pakistan will be more innovation and technology based agriculture that makes efficient and sustainable use of natural resources; redirect public sector agriculture expenditure by focusing agriculture subsidies to socio-economic groups that need it most such as small farmers, landless, women, and nomads and transhumant, and public investments in creation of knowledge, technology and essential infrastructure that would facilitate and encourage private investments by raising profitability of agriculture and ruralbased activities; and ensure that food is accessible to all sections of the population, in particular vulnerable groups such as children and women, and is prepared, stored and consumed in a way that ensures nutritional security.

To better understand the root causes of declining agriculture and failure of agricultural policies in Pakistan, it is useful to explore that how agricultural policies are made in Pakistan.

\section{Agricultural Policy Making Process in Pakistan}

Agriculture is the most important sector of the country's economy (Ahmad \& Farooq, 2010; Akram, Alam, \& Iqbal, 2018; Awan \& Yaseen, 2017; M. H. Khan \& Imam, 1985; Malik et al., 2016; Government of Pakistan, 2017). The agriculture sector of Pakistan is a provincial subject. However, the sector is assisted by various federal and provincial government departments. Federal institutions are mainly responsible for formulating and coordinating national policies and strategies, such as the import and export of agricultural inputs and commodities, setting prices of inputs and outputs, enforcing phytosanitary and quarantine regulations, approval of varieties and seed certification, standardization, compliance of grades and standards, providing support to national research institutions, and managing marine fisheries resources (Greer \& Jagirdar, 2006). There is a mess of institutions involved in agriculture policymaking in the country as mentioned in a report published by Asian Development Bank in 2006. According to the report, there is often excessive government intervention and too many regulatory departments which are the major impediments in the promotion of the sector. Policy decisions are mostly based on crisis management and the need to provide a quick fix to a problem, the report concludes. Ahmad and Farooq (2010) while discussing major flaws in the existing wheat policies find that considerable inefficiencies in managing wheat surpluses as the quantities procured were beyond the storage capacities available with the government departments-hiring private storage facilities at a huge cost to the nation. It means that the government do not have data of storage capacities or even it has the data but not making use of relevant data for managing wheat surpluses. Similarly, Spielman et. al (2016) finds that there is decline in evidence-based policy making related to agricultural sector issues in Pakistan. According to him, "as a result, growth in the rural economy has lost momentum, leaving Pakistan's rural population to face continuing high levels of poverty, and food insecurity, as well as limited access to the public services and markets required for a modern economy". 
Commenting on the policy making process in Pakistan, Saeed (2013) finds that, "As far as the development of policies is concerned, Pakistan has a unique process of developing public policies". Because, "Pakistan inherited a very strong bureaucratic structure which was developed to cater the needs of the colonial powers" (Wilder, 2009). Therefore, "The policy making was basically the domain of the colonial rulers and then bureaucracy was trained to perform this task at local level" (Saeed, 2013). Whereas according to Sial (2011), "State has lost its capacity to frame its policies according to its national priorities. Its parliament seems to have imperfect control over decision-making process. Parliament doesn't seem to have selfregulating capacity" (p. 127). Islam (2001) notes that "the legislatures have traditionally played minimal role in the country's governance". Saeed (2013) concludes in a policy making case study in Pakistan that, "Pakistan ever since its independence has been under the influence of super powers and donor agencies and most of the policies adopted and implemented in the Pakistan has been suggested or enforced by them and the role of legislature in this regard has not been significant at all". Commenting on the policy formulation process in Pakistan, Husain (2013) notes that, "Policymaking in Pakistan deviates from the ideal process". Meaning that the process is not in accordance with policy literature. According to him, there are six deviations. First, "The stakeholder consultation is either superficial or the views of the stakeholders, if found at variance with those of the formulators, do not find any place in the revised documents". Similarly, "Ministers feel personally offended if their policy documents are criticized by other ministers". "Some slick players with the gift of the gab can make impressive PowerPoint presentations and mesmerise the audience. They create the impression that things are going well while the facts are to the contrary". Therefore, "underlying problems remain unaddressed".

Fifth, the capacity of the ministries and provincial departments in preparing policy papers is limited. They do not have the necessary expertise or competence in the subject to come up with evidence-based options. The use of systematic data is normally shunned. And finally, the communication strategy of explaining the rationale and disseminating the policy widely is almost non-existent in most cases. As the success of the policy depends upon people outside the government their understanding and support are absolutely crucial.

Investigating public policy making in Pakistan, Hussain (2008) finds that policy making has been captured by feudal elites and other powerful interest groups. According to him, “...policy makers work under pressures of deadlines" Therefore, [data] are of no use to them if they are made available after the deadlines. He is of the view that the policy recommendations are not implement-able as the researcher; do not take cognizance of the constraints faced by the policy makers. He asserts that public policy can be informed and made effective if these are based on primary data collection, surveys. Structured interviews, field visits and observations. Commenting on the need of multidisciplinary approach, he argues that, "Most public policy Issues in Pakistan can be resolved only if we dissect them under a multidisciplinary microscope rather than a single lens prism or a par1icular discipline'. It means we must have data of various disciplines to inform policy making. Having multiple datasets would help to stop "policy makers from indulging in irresponsible policies, low return pet projects and rent seeking by their political cronies" (Husain, 2001). 


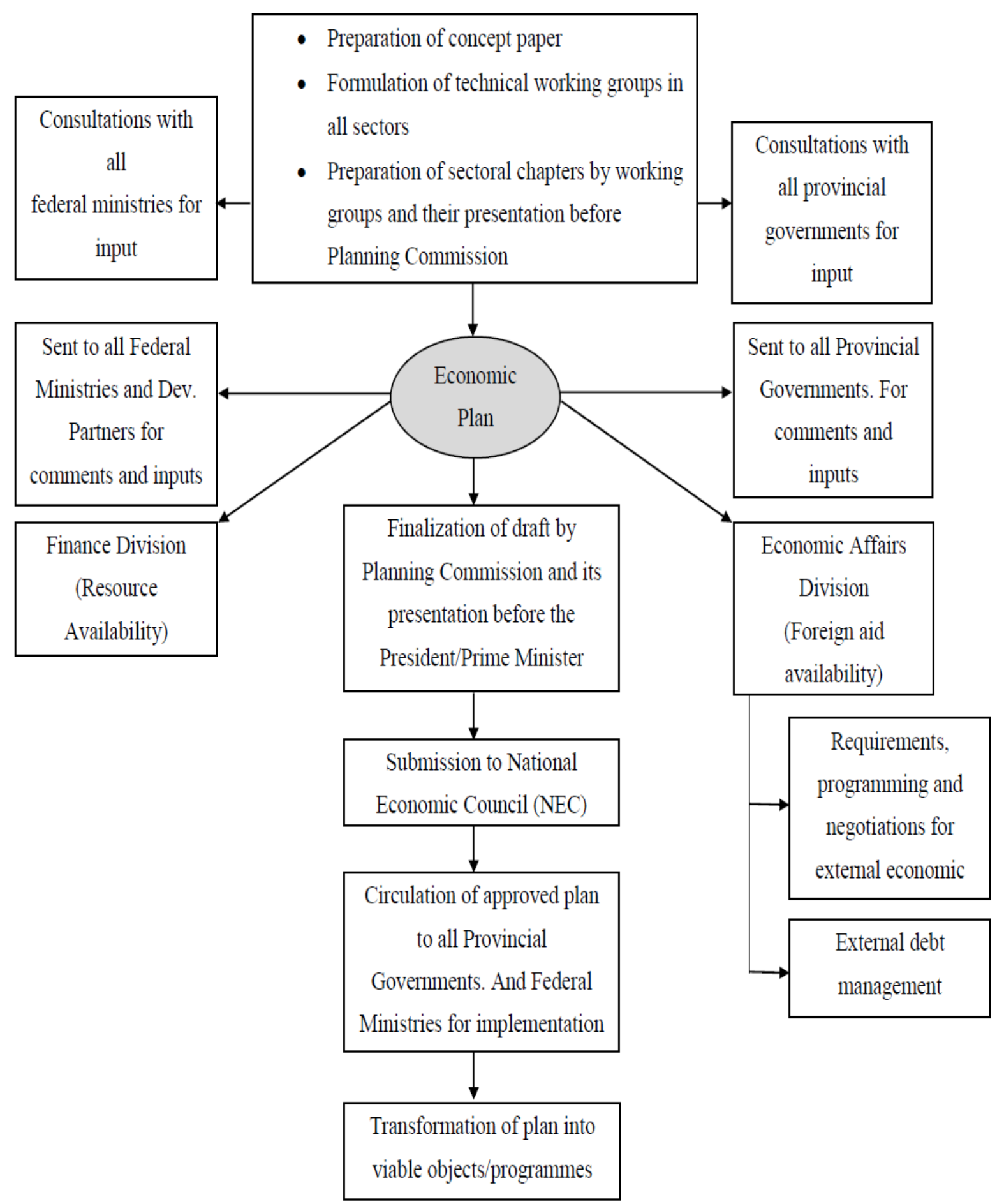

Figure 3: Policy-making process in Pakistan

"The financial, technical and human resources play critical role in formulation and implementation of public policy. In case of Pakistan, the country has always has been in short of financial resources to implement the public welfare projects and there is no proper utilization of resources in any sphere of development or policy making process. Due to the corruption and inefficiency of government functionaries, the available resources are always mismanaged and underutilized. The injustice taxation policy is the main reason of shortages of financial resources in the country. Since the inception of Pakistan, government has failed to implement a viable taxation policy where every citizen irrespective of their positions and political influences should pay the required taxes and evaders liable to be punished according 
to the law. Due to this reason, the budget formulation history of the country has depicted that most of the presented budgets had been in deficit. It is prudent that there must be sufficient resources for the successful formulation and implementation of public policies to obtain the desired objectives" (Sirajul, 2015). Jabeen, Jadoon, \& Salman (2016) analyzed public policy making process and strategies in the specific context of Pakistan. Their findings are that, "existing process and strategies of policy making are quite generic, linear and mainstream which provide an overly simplistic and general understanding of the approach in which public policies are formulated". Political interests play an important role in policy making of the country.

Khalid, $\quad$ Mushtaq, \& Naveed (2016) argue that public policy means the actions of the government in order to solve the problems being faced by the nation. They find that there are three elements of a public policy i.e. what is the problem, its players and their policies. They identify factors which cause failures of public policies in Pakistan. According to them, the factors include, lack of relevant information, lack of coordination among government institutions, irrelevant education of the politicians, lack of financial resources, corruption and untrained civil servants in the specific discipline, political instability and lack of research.

From above discussion, it can be concluded that policy making capabilities of the government institutions in the country can be seen as poor. The reasons can include; lack of coordination, lack of usage of scientific data and research, underperforming institutions, exclusion of some relevant stakeholders and relying on inaccurate and incomplete data. There is a need to change the current policy making process as governments in Pakistan secure their own interests, and the vast majority of people including farmers are far from the basic necessities and facilities(M. Abbas et al., 2016). Therefore, data should be used for evidence based policy making instead of telling tales as "to assess the growth in global demand for agricultural output, one needs estimates from many sources (Norton, 2016). The study suggest "to enhance the development policymaking capacity of the institutions, by arranging capacitybuilding and training programmes for the policymakers" (United Nations, 2019) in the areas of agricultural development planning and financial analysis etc.

\section{Specifics of Agricultural Information and Policies}

Agriculture is spatial in nature. All agricultural activities take place at some geographic place. Similarly, "all agricultural information is located in a certain geographic space, and possesses spatial variation. Therefore, all agricultural information may be called agricultural geographic information"(Y. Q. Huang et al., 2012). It is argued that almost all the problems faced by agriculture are spatial. Agricultural policies are crafted for addressing these spatial problems and obviously spatial decisions are made. The final decision is based on two main questions: 1) what should be done? (Action) and 2) where it should be implemented (Location)? (Chakhar \& Mousseau, 2008; Malczewski, 1999; Malczewski \& Rinner, 2015). The first question refers to the policy or decision-making process, and the second concerns the 'receptor' of the final decision, namely, the most suitable location for the development of a specific agricultural activity. Most application that are built in agriculture exploit spatial information. Farmers consider themselves as 'information poor', and news about new agricultural technologies that improve productivity is not reaching them(Government of Pakistan, 2014). Agricultural information consists of four interrelated components, namely spatial position, spatial relationship, attribute, and temporal property(Fonseca et al., 2003). Agricultural information "products (such as irrigation data, soil survey data, and cropland data) are widely used in many research areas, ranging from agricultural sustainability, food security, and biodiversity, to natural resources monitoring, disaster assessment, carbon and accounting bioenergy"(Han et al., 2014). Thus, the information plays an important role in 
agricultural production(Y. Q. Huang et al., 2012) and decision as well as policy making. The information is produced by various organizations. Therefore it has different data formats and specifications thus making it difficult to integrate and share (Y. Q. Huang et al., 2012). In this situation, users can not make use of the information at different spatial scales for agricultural assessment and analysis(Yang et al., 2011).

The critical review of scientific literature indicates that spatial data of various kinds is required for sustainable agriculture, agricultural policies and practices. For understanding the local agricultural context of a region and to predict precisely requires accurate "geospatial data on land use, productivity, soils, climate, water availability, institutions, and so on" (Norton, 2016). Information and education are critical for the policy makers, farmers and consumers to make appropriate policy (Government of Pakistan, 2018c).

\subsection{Importance of Data for Policy-Making}

Information and education are critical for the policy makers, farmers and consumers to make appropriate policy (Government of Pakistan, 2018c). Baumgartner and Jones (2015) explored the role of information in public policies. They argue that, "To understand a complex issue, governments must gather information about the issue". They further suggest two types of information: entropic information and expert information. Entropic information, which can be described as incorporating 'diverse viewpoints into a decision-making process' (p. 78), is a good fit for problem discovery, while expert information is useful for problem's solution.

While highlighting the need of more information gathering, they find that, "the more information one gathers, the more one understands the multidimensional character of the issue, and the more one might be tempted to create a range of public policy programs designed to address different elements of [the problem].

They define relationship between information and public policy as, "Information is critical for problem solving, and hence how governments recognize, organize, and respond to information is essential to understand public policy, the outputs of government activities".

\subsection{Role of Spatial Information within Policy-making}

Monmonier (1982) argue that map is the principal medium for communicating geographic information. According to him, map-making (cartography) is a policy science. He notes that most of the maps are made by governments and enormous amounts are spent by governments and private firms for the collection and presentation of spatial data. He argues the role of cartographers as individuals in map making "but the important decisions are institutionalfederal, political or corporate, rather than individual". He highlights that "It is the information, not the map, that will be the principal product, and it is the agency or information network, not the map-maker, that will be the primary provider". He underpins, "in communicating geographic information, public policy is a more significant factor than the eye-brain system". He asserts that "if the information is not collected, organized, and disseminated, then the best design talent and the most astute theories of graphic communication are of no avail". He argues that major constraints to collection, organization and dissemination of GI are institutional and political, not technical in nature.

While discussing cartography as a policy science, he stresses the need to understand "institutional aspects of information management'. According to him, “...policy specialists in economics study and debate government and private-sector programmes to increase employment and productivity, so too are policy specialists in geographic cartography needed to evaluate the effectiveness of public and private efforts to collect, organise and disseminate geographic information". He recognized the need of policy makers and scientists for better information and to "evaluate the effectiveness of public and private efforts to collect, organise and disseminate geographic information". He points out that, "Cartographers and geographers have a stake in policy science, for in the same sense that there is need for a policy on energy 
and natural resources, there is need for a policy on mapping and geographic information. Geographic information has the potential of becoming a major pillar of modern (Monmonier, 1982) public policy making process. A policy oriented geographic information concentration has much (Monmonier, 1982) to do with policy making process.

Coppock (1974) grasped the reality of increasing awareness about spatial dimensions of public policies. He argues, "it is highly appropriate to consider the role of geography [and geographic information] in policy-making". He further sheds light on the crucial fact that policy makers themselves generally don't have awareness regarding the spatial dimensions of the problems or policies that may be due to the reason that geography get relatively low importance in the academic institutions. According to him, "Understanding policies and processes of decision-making is thus essential to an understanding of the contemporary geography". It is also important to have "the ability to analyze the spatial dimensions of the problems and, more particularly, to handle, analyze and interpret spatially distributed data". In agriculture, resource management is significantly important and it has a spatial dimension according to (Coppock, 1974). Geographic information can help to understand, identify and mobilize the necessary resources according to local needs of the various regions. He finds that spatial dimension is a major ingredient of all problems and resource management. To offer solution for the large-scale projects which policy-makers face require handling of large quantities of data, he concludes.

The implementation of GIS--coupled with a rigorous approach to information management- provides the public sector with a significant opportunity to improve the effectiveness of policy and the efficiency of programmes (Worrall \& Bond, 1997).

Geographic information is critical to promote economic development, improve our stewardship of natural resources and to protect the environment. Modern technology now permits improved acquisition, distribution, and utilisation of geographic (or geospatial) data and mapping. The National Performance Review has recommended that the Executive Branch develop, in cooperation with State, local and tribal governments and the private sector, a coordinated National Spatial Data Infrastructure to support public and private sector applications of geospatial data in such areas as transportation, community development, agriculture, emergency response, environmental management and information technology(Coordinating Geographic Data Acquisition and Access, the National Spatial Data Infrastructure, Executive Order 12906, Federal Register 59,17671-17674, 1994).

Harris \& Hooper (2004) assessed through textual analysis, the concept and practice of 'spatial planning' in the context of the formulation of public policies in Wales providing a spatial context for major development decisions and for the allocation of resources. They reviewed various sectorial policy documents published by the National Assembly of Wales for spatial content. They concluded that "a spatial planning approach, if successfully developed and enhanced, offers real value in the development of public policy" whereas "space and place are in fact relevant and significant in the development of public policy".

Barjolle, Sylvander, \& Thévenod-Mottet (2011) find that GI has been instrumental in EU common agricultural policy (CAP) and rural development. They argue, "Producers [of agricultural products] may be at an advantage or a disadvantage by virtue of their geographical location and their proximity to consumer centres". They note, "for adjusting supply and demand on generic markets for agricultural commodities, states have set up [GI] systems for sector regulation in the context of their agricultural policies".

Simukanga, Muhone, Mulenga, Phiri, \& Nyirenda (2018) implemented an agricultural geographical information system in South Africa. They argue that, "By understanding geography and people's relationship to location, we can make informed decisions". They highlight the importance of GIS and spatio-temporal data for policy makers, "Researchers and policy makers may integrate spatial, temporal, and socio-economic data [using GIS] in order 
to get better manageability, higher and quality productivity". They note that reliable crop information is essential for informed decision and policy making.

Huang, CHEN, YU, HUANG, \& GU (2018) assessed available remote sensing data resources for precision agriculture. They described and adapted a five-layer-fifteen level (FLFL) satellite remote sensing data management structure for precision agriculture. They argue, "The key of agricultural remote sensing is, with global positioning data and geographic information, to produce spatially-varied data for subsequent precision agricultural operations".

\subsection{Spatial Data for Agricultural Policies}

Geospatial data and technologies are being widely used because of their capability to improve development and planning of a nation(Majeed \& Hanafiah, 2018). Masser (2007) underlines the importance of location as a key factor in policy making. He argues that spatial databases need to be assembled and made available at the national level for informing national policies. The role of better data for better policies is also endorsed by (FAO, 2014b).

The spatial data required for agricultural policies can include the following:

\section{Geospatial data}

Precision agriculture demands collection, storage, sharing and analysis of large amounts of geospatial data(Nash et al., 2009). Geospatial data coupled with web and mobile application can help policymakers to understand, visualize and analyze the impact of agriculture on the environment(Kamilaris et al., 2018). Geospatial data includes topographic data that is used as base map to integrate various kinds of thematic information such as soil, rainfall and population. Geospatial data can include satellite imagery, too.

\section{Hydrological data}

Rehman et al. (2019) identified three major factors impeding agricultural productivity in Pakistan including water availability. Hydrological data helps to understand the potential availability of water to crops, livestock and fisheries etc. Agriculture is usually the applicant for water(Norton, 2016). Therefore, hydrological data relates to water resources such as lakes, rivers, irrigation channels, wells and tube wells etc.

\section{Digital Elevation Model (DEM)}

Digital elevation model (DEM) plays an important role in agricultural planning such as extraction of drainage networks(Wu et al., 2019), cultivation planning(Jasinski et al., 2005) and appraisal of agricultural lands(Sakai \& Chikatsu, 2008).

\section{Cadaster (Land ownership) data}

Information related to the location, size, boundaries and ownership of land parcels comes under this category. This is important to know who owns a land parcel so that necessary agricultural inputs can be delivered to the right person. Moreover, land ownership information can be effectively used to allot land to agrarians who donot own agricultural land but possess formal education in agricultural sciences(Elahi et al., 2020). For example, in 2009, the Government of Punjab significantly increased the yield of major crops such as wheat, rice, cotton, and sugarcane by $16.5,14.2,12.3$, and $23.2 \%$, respectively by allotting land to agrarians (Elahi et al., 2020). Having land ownership information will be helpful to get back state land encroached by people and therefore contribute towards timely and better management of agricultural land(Elahi et al., 2015; Jehangir et al., 2007; Jiang et al., 2017; Li et al., 2017). Also, governments from time to time announce subsidies on agricultural inputs such as seeds, pesticides and fertilizers etc for farmers. Therefore, having land ownership information would be helpful in implementing and informing agricultural policies.

\section{Land use data}

Land use data helps to identify the human activity or economic function on a specific piece of land, e.g. urban use, industrial use, etc. In Pakistan, due to non-existence of dedicated land use system, changes in land use are occurring almost every day and there are ambiguities in the 
existing policies in defining different forms of formally and informally recognized land rights (A. Ullah et al., 2020). Therefore, there is dire need to have data on land use in the country. Data regarding actual use of land such as agricultural, residential, commercial etc. This type of data helps to determine the magnitude of land being used for agriculture and therefore helps to understand the pattern of increasing or decreasing agricultural land in a region. The data can be helpful to analyze the required resources such as water, energy and physical infrastructure for the development of agriculture in a specific area.

\section{Land cover data}

Land cover data is used to identify type of features present on the land. It refers to a physical property or material, e.g. water, sand, etc.

\section{Remote Sensing}

The data captured by remote sensing satellites "assist with the assessment of crop condition and crop condition anomalies, which can then be used to infer information on yield, area and production"(Fritz et al., 2019). Similarly, Zhang et al. (2019) finds that "high spatial resolution (HSR) remote sensing images are a reliable source for classifying urban land use.

\section{Crops data}

Data related to location and types of major crops grown is also useful as it helps to understand, visualize and analyze the area under major crops such as wheat, rice, sugarcane and maize etc as finds (Ali Chandio et al., 2016).

\section{Research data}

Data generated by researchers during their agricultural research is also an important outcome as the data can be re-used by other stakeholders including but not limited to governments and researchers. Neylon, (2017) asserts that research data is a quite useful outcome of a research that can be benefited in some other research studies.

\section{Soil data}

Accurate information about soils is required for land resource management, monitoring, and policy-making(Lucà et al., 2018). Therefore, soil is vital for informed decision and policy making.

\section{Agricultural census}

It includes data such as employment statistics, land utilization, area under important crops, livestock population, agricultural machinery statistics, crop yields and fertilizer usage as fertilizers are the main inputs that are used to achieve high and fast rates of agricultural returns(Rehman et al., 2019).

\section{Weather / meteorological data}

In order to predict and advise farmers, weather or meteorological data is of prime importance. Zhai et al. (2020) argue for the same, " ... meteorological information, soil conditions, marketing demands, and land uses, can be collected, analyzed, and processed for assisting farmers in making appropriate decisions and obtaining higher profits". Data of temperatures, rainfall, sunshine duration, moisture, humidity, and wind speed can include this category of data.

\section{Pest and disease data}

Pest attacks cause a major damage to agriculture. Chougule, Jha, \& Mukhopadhyay, (2016) find that, "[agriculture decision support systems] ADSSs are able to warn farmers about possible occurrences of pests and diseases, helping them to take certain precautions to avoid further losses". But it requires data on pests and diseases to prevent the potential loss. This information will also be of great use for companies engaged in preparation of pesticides.

\section{Data on natural hazards}

Natural hazards such as droughts, floods and landslides have direct and negative impact on agricultural productivity. Simukanga et al. (2018) argues for the same, " [food security] is affected by factors such as poverty, health, food production, political stability, infrastructure, 
access to markets, and natural hazards". Therefore, having historical and predicted datasets on natural hazards can help in mitigation and preparedness efforts while making sustainable agricultural policies for a specific region.

From the literature cited above, it reveals that various kind of spatial datasets are needed for evidence-based agriculture policy making. The summary of the key data sets required is listed in Table 4 and Table 5.

Table 4: Main spatial datasets to address agriculture issues

\begin{tabular}{ll}
\hline Spatial data & References \\
\hline Geospatial Data & Fritz et al. (2019), Kamilaris et al. (2018); Nash et al. \\
& (2009); Khan (2011) \\
Hydrological data & Fritz et al. (2019); Rehman et al. (2019); Norton \\
& (2016); Ali \& Ahmad, (2012); Padilla-Pérez \& Gaudin \\
& (2014); Moro (2016); ADB (2009); Raja (2015); Bai et \\
& al. (2016) \\
Cadastre (land ownership) & Elahi et al. (2015); Jehangir, Masih, \& Ahmed (2007); \\
data & Jiang et al. (2017); Li et al. (2017) \\
Land use data & A. Ullah et al. (2020), Zhai et al. (2020); Khan, (2011) \\
Crops data & Fritz et al. (2019); Ali Chandio, Jiang, Ali Joyo, \& \\
& Rehman (2016);Government of Pakistan (2016); Raja \\
& (2015); Reidsma, Ewert, Lansink, \& Leemans (2010); \\
& Bai et al. (2016); Khan (2011) \\
Research data & Neylon (2017) \\
Soil data & Fritz et al. (2019); Zhai et al. (2020); Lucà, Buttafuoco, \\
& \& Terranova (2018);OECD/FAO (2016); Reidsma et \\
& al. (2010); Padilla-Pérez \& Gaudin (2014) \\
Agricultural census & Fritz et al. (2019); Rehman et al. (2019), Morton \\
& (2007); Padilla-Pérez \& Gaudin (2014); Raja (2015) \\
Weather / meteorological & Zhai et al. (2020); Fritz et al. (2019); OECD/FAO \\
data & (2016); Khan (2011) \\
Pest and disease data & Chougule, Jha, \& Mukhopadhyay (2016) \\
Data on natural hazards & Simukanga et al. (2018) \\
Remote Sensing & Zhang et al. (2019); Fritz et al. (2019); Reidsma et \\
Land cover data & al.(2010); Khan (2011) \\
Climate change & Khan (2011); Fritz et al. (2019) \\
& Khan (2011); Government of Pakistan (2016); \\
& Government of Pakistan (2015); Fatima \& Yousaf \\
& (2014); Dinar, (1993); CCAFS (2016); Shirgure \& \\
& Shirgure (2013); Steenwerth et al. (2014); Moro \\
& (2016); ADB (2009); OECD (2015);Zhai et al. (2020) \\
\hline &
\end{tabular}

\section{Impact of Climate Change on agriculture}

The negative impact of climate change on agriculture is well acknowledged in theory and practice. It can cause for example desertification, salinisation, land degradation and soil erosion, saltwater intrusion due to rise in sea level and flooding. In the context of Pakistan, following literature was sighted.

Prăvălie (2016) finds that desertification is affecting 38 of 48 countries in Asia and it is a serious problem in Pakistan (Irshad et al., 2007; Lal, 2018). Major river basins such as Indus Basin in Pakistan is undergoing salinisation (Aslam \& Prathapar, 2006). In Pakistan, about 6.2 Mha of agricultural land is affected by salinity(NIAB, 1997). Land degradation affects people and ecosystems throughout the planet and it is a driver of climate change(Shukla et al., 2019, p.53). 
Saltwater intrusion is also one of the problems being faced in coastal areas of Pakistan. The Indus Delta, located near Karachi is an example of seawater intrusion and land degradation due to climatic and environmental conditions(Rasul et al., 2012). Salinisation and waterlogging in the provinces of Punjab and Sindh is due to over-irrigation (Chandio et al., 2011).

Agriculture in Pakistan has been negatively affected by climate change(Shukla et al., 2019, p.452). Abbas et al. (2017) finds that from 1980 to 2014, there is an average shift of 4.6 days per decade earlier in the case of spring maize growing periods whereas sowing of autumn maize has been delayed 3.0 days per decade. Similarly, Tariq et al. (2018) found that due to rise in temperature from 1980 to 2016, there are shifts in sowing, emergence, anthesis, and maturity for fall and spring crops.

In developing countries, floods negatively impact access to food and livelihoods. In 2010, the unprecedented rainfall in Indus valley of Pakistan led to flooding, affecting the lives and livelihoods of 20 million people. There is evidence that these effects were due to climate change (Mann et al., 2017). Accordingly, the food prices were high causing more food insecurity in the country(Shukla et al., 2019,p.516).

From above cited literature it reveals that climate change is the major threat to agriculture. Therefore, it needs a special mention. Location information (spatial data) typically plays an important role in climate change studies(Below et al., 2015; Hinkel, 2011; Tiwari et al., 2008; Vincent, 2007). Paudyal, Dev Raj and McDougall, Kevin and Apan (2011) in their research identified main spatial datasets to study climate change in a region.

Table 5: Main spatial datasets to address climate change (Source: Paudyal, Dev Raj and McDougall, Kevin and Apan, 2011)

\begin{tabular}{lccc}
\hline Spatial Data & Local & State & National \\
\hline Atmospheric & & & $\times$ \\
Climate & & $\times$ & \\
Land Use/Land Cover & $\times$ & $\times$ & \\
Digital Elevation Model & $\times$ & $\times$ & \\
Demography/Population & & $\times$ & \\
Distribution & $\times$ & $\times$ & \\
Soil and Geography & $\times$ & $\times$ & \\
Aquifer and Ground Water & $\times$ & $\times$ & \\
Surface Water & $\times$ & $\times$ & \\
Watershed/Catchment & $\times$ & $\times$ & \\
Landownership/Cadastre & & $\times$ & \\
Infrastructure & & $\times$ & \\
Protected Areas & & & \\
Source of Pollution & $\times$ & $\times$ & \\
Topographic base & $\times$ & $\times$ & \\
Ariel Photograph/Orthophoto & $\times$ & $\times$ & \\
Buildings & & $\times$ \\
Transport & & $\times$ & \\
Air Quality & & & \\
Ecosystems Zones & & & \\
Vegetation & & $\times$ & \\
Rainfall & & & \\
\hline
\end{tabular}


From Table 4 and 5, it reveals that 25 spatial datasets of various kinds are required to address issues faced by agriculture. Practically, it is impossible for a single organization to collect, maintain and provide these datasets due to mandate constraints. But it does not include datasets required for agricultural monitoring and land management which is described next.

\section{For agricultural monitoring}

Fritz et al. (2019) in their recent study compared eight main global and regional agricultural monitoring systems based on the input data and models being used. They identified forty thematic datasets required for agricultural monitoring. The authors found fundamental gaps in the data and data collection methods. Accordingly, they suggest to harmonize data collection methods.

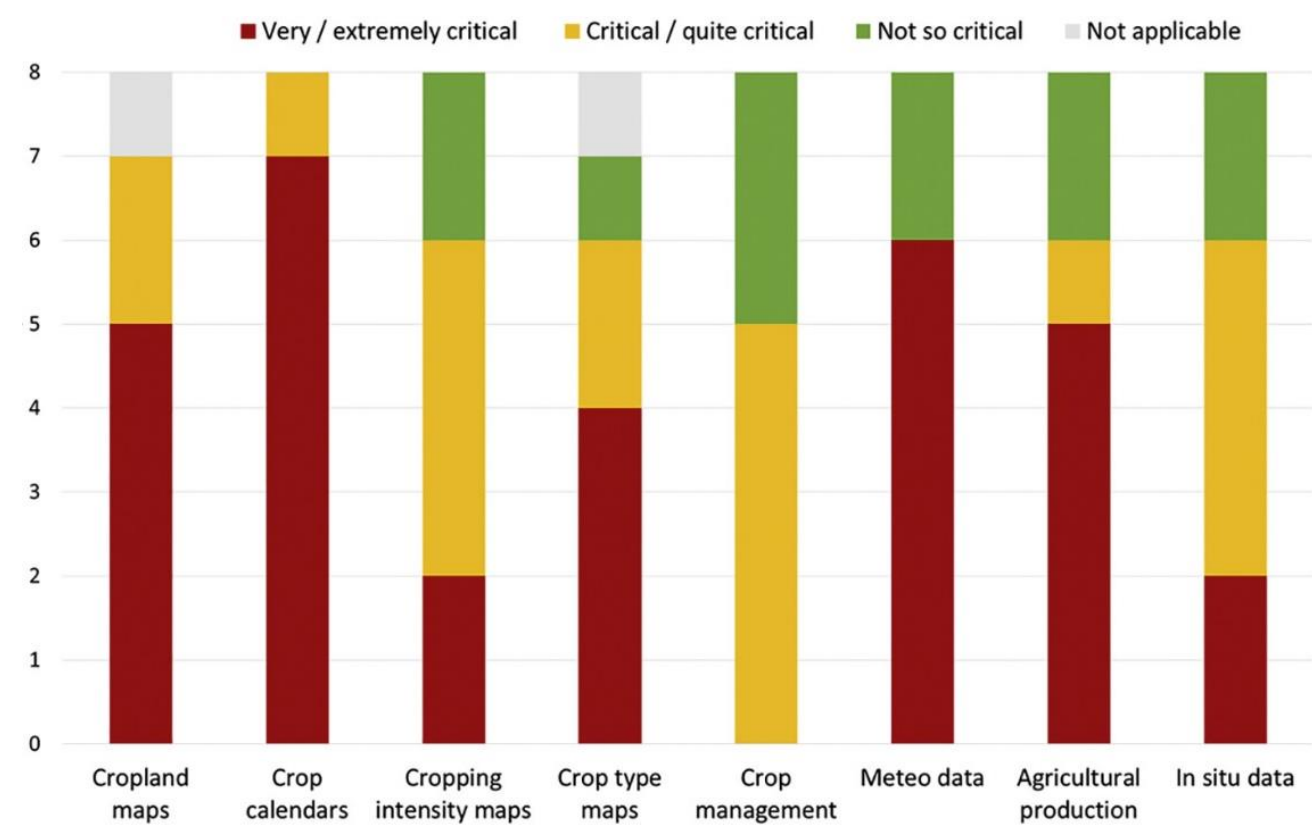

Figure 4: The level of importance of datasets for agricultural monitoring Source: Fritz et al. (2019)

\section{For land management}

Erb et al. (2017) from an inventory of the main data sets available for different land management practices, found that ten various kinds of datasets are crucial for land management in order to understand and address the "global sustainability challenges such as climate change, biodiversity loss and food security". The datasets include forestry harvest, tree species, grazing and mowing harvest. crop harvest and residue management, crop species, $\mathrm{N}$-fertilization, tillage, irrigation and wetland drainage, and fire management.

\section{Inventory of necessary spatial datasets for agriculture: The synthesis}

To synthesis all the above mentioned spatial datasets, Table 6 lists all the necessary spatial datasets required for agricultural practices and policy-making. The table also mentions user as well as producer organizations of the datasets in Pakistan.

Table 6: Use-produce-origin description for types of geographic information necessary for agricultural policies

(adapted from Chantillon et al., 2017)

\begin{tabular}{ll}
\multicolumn{1}{c}{ Type of data } & \multicolumn{1}{c}{ Description Use-Prod } \\
\hline $\begin{array}{l}\text { Hydrological Data (It is the data regarding } \\
\text { water resources) }\end{array}$ & $\bullet$ user organisations \\
& $\bullet$ producing organisations
\end{tabular}




\section{Type of data}

Cadastre (land ownership) Data

(It is the data which defines the geographic extent of the past, current, and future rights and interests in real property and the spatial information needed to describe that geographic extent)

Land Use Data

(It is the data which tells us about the human use of land. Land use involves the management and modification of natural environment or wilderness into built environment such as fields, pastures, and settlements)

Crops Data (It tells us about the useful information regarding crops maps, crop intensity and crops management)

Research Data (It tells us about the information that has been collected, observed, generated or created to validate original research findings)

Soil Data (It tells us about any information regarding the soil and their types)

Agricultural Census Data (The Census of Agriculture is a census conducted that provides the only source of uniform, comprehensive agricultural data)

Weather / Meteorological Data (The weather/ meteorological data provides us the useful information regarding weather conditions and also the changes in them)

Pest and Disease Data (This data give information regarding any animal or plant detrimental to humans or human concerns, including crops, livestock and forestry, among others)

Natural Hazards Data (It is the data regarding the natural disasters including floods, droughts and land sliding)

Remote Sensing Data (Remote sensing is the
Description Use-Produce-Origin

- The data mainly originate from Water and

Power Development Authority (WAPDA).

- 7 user organisations

- 4 producing organisations

- The data mainly originate from the provincial governments.

- 7 user organisations

- 5 producing organisations

- The data mainly originate from the provincial governments.

- 4 user organisations

- 5 producing organisations

- The data mainly originate from the provincial governments.

- 1 user organisations

- 18 producing organisations

- The data mainly originate from the academic institutions.

- 20 user organisations

- 4 producing organisations

- The data mainly originate from the provincial governments.

- 15 user organisations

- 5 producing organisations

- The data mainly originate from the provincial governments and is consolidated at the federal level.

- 10 user organisations

- 1 producing organisations

- The data mainly originate from the Pakistan

Meteorological Department.

- 4 user organisations

- 1 producing organisations

- The data mainly originate from the

- 10 user organisations

- 5 producing organisations

- The data mainly originate from the provincial governments and National Disaster Management Authority (NDMA).

- 5 user organisations 


\begin{tabular}{l} 
Type of data \\
\hline science of obtaining information about \\
objects or areas from a distance, typically \\
from aircraft or satellites) \\
Land cover Data (Land cover data documents \\
how much of a region is covered by forests, \\
wetlands, impervious surfaces, agriculture) \\
Digital Elevation Model Data \\
(It represents the relief of a surface between \\
points of known elevation)
\end{tabular}

Demography/Population Data

(Data collected about the characteristics of the population, e.g. age, gender and income)

\section{Distribution Data}

(The distribution of a statistical data set (or a population) is a listing or function showing all the possible values (or intervals) of the data and how often they occur i.e. temporal aspects)

Aquifer and Ground Water Data (Aquifer/Ground Water Data is all the groundwater present in the area)

\section{Surface Water Data}

(It tells us about the water over the surface of the earth)

\section{Watershed/Catchment Data}

(The Catchment data/watershed data tells us about the area from which a city, service or institution attracts a population that uses its services)

\section{Infrastructure Data}

(Infrastructure data informs about fundamental physical facilities and systems serving a region such as telecom, transport and health facilities)

\section{Protected Areas Data}

(Protected areas give information about the locations which receive protection because of their known natural, ecological or cultural values)

Source of Pollution Data

\section{Description Use-Produce-Origin}

- 1 producing organisations

- The data mainly originate from Space and Upper Atmosphere Research Commission (SUPARCO).

- 7 user organisations

- 1 producing organisations

- The data mainly originate from Space and Upper Atmosphere Research Commission (SUPARCO).

- 10 user organisations

- 1 producing organisations

- The data mainly originate from Space and Upper Atmosphere Research Commission (SUPARCO).

- 15 user organisations

- 1 producing organisations

- The data mainly originate from Pakistan Bureau of Statistics (PBS).

- 15 user organisations

- 1 producing organisations

- The data mainly originate from Pakistan Bureau of Statistics (PBS).

- 10 user organisations

- 1 producing organisations

- The data mainly originate from Water and Power Development Authority (WAPDA).

- 10 user organisations

- 1 producing organisations

- The data mainly originate from Water and Power Development Authority (WAPDA).

- 10 user organisations

- 1 producing organisations

- The data mainly originate from Climate, Energy \& Water Research Institute (CEWRI).

- 5 user organisations

- 1 producing organisations

- The data mainly originate from Planning Commission of Pakistan.

- 10 user organisations

- 4 producing organisations

- The data mainly originate from the provincial governments.

- 4 user organisations 


\section{Type of data}

(It gives information about the three sources of pollution; mobile, stationary and area sources. For example, cars, buses, planes, trucks, and trains are moble sources of pollution. Stationary sources can include power plants, oil refineries, industrial facilities, and factories. Area sources include agricultural areas, cities, and wood burning fireplaces)

Topographic Base Map Data

(Topographic data are information about natural and man-made features that appear on the earth)

Ariel Photograph (It is airborne imagery)

Buildings Data

(It refers to the characteristics of buildings)

Transport Data

(It is the data related to the means of transportation)

Air Quality Data

(It indicates how clean or unhealthy air is in a region)

Ecosystems Zones Data

(It deals with the precipitation variability and annual amounts region)

\section{Vegetation Data}

(It refers to type of plant)

\section{Rainfall Data}

(It is the data regarding rainfall)

Agricultural Production Data

(It refers to the production of agricultural crops)

\section{Description Use-Produce-Origin}

- 1 producing organisations

- The data mainly originate from the

Ministry of Climate Change.

- 30 user organisations

- 1 producing organisations

- The data mainly originate from Survey of

Pakistan (SoP).

- 4 user organisations

- 1 producing organisations

- The data mainly originate from Survey of

Pakistan (SoP).

- 5 user organisations

- 4 producing organisations

- The data mainly originate from provincial governments.

- 20 user organisations

- 6 producing organisations

- The data mainly originate from Survey of Pakistan (SoP).

- 5 user organisations

- 1 producing organisations

- The data mainly originate from Ministry of

Climate Change.

- 4 user organisations

intensity, - Could not be specified.

across a $\bullet$ Could not be specified.

- 10 user organisations

- 5 producing organisations

- The data mainly originate from SUPARCO.

- 15 user organisations

-1 producing organisations

- The data mainly originate from Pakistan

Meteorological Department.

- 15 user organisations

- 10 producing organisations

- The data mainly originate from the provincial governments. 


\begin{tabular}{ll}
\hline \multicolumn{1}{c}{ Type of data } & \multicolumn{1}{c}{ Description Use-Produce-Origin } \\
\hline $\begin{array}{l}\text { In Situ Measurements } \\
\text { (These are measurements that are made on }\end{array}$ & $\begin{array}{l}\cdot 32 \text { user organisations } \\
\text { ground) }\end{array}$ \\
& $\begin{array}{l}- \text { The data mainly originate from Survey of } \\
\text { Pakistan. }\end{array}$ \\
\hline
\end{tabular}

As shown in Table 6, thirty (30) types of geographic information is necessarily required for agricultural policy-making. It is also evident from the table that several organizations at various spatial scales ranging from national to local level are engaged in producing the information. The number of user organizations of the information are up to 32 in certain cases. This scenario calls for implementation of national spatial data infrastructure (NSDI) for efficient management and sharing of the data to inform agricultural policies and practices.

\section{Conclusions and recommendations}

Agriculture in Pakistan, "despite its falling share in national income, continues to attract considerable attention in policy debates because of its strategic importance to the livelihood of farming communities, poverty reduction and national food security"(Birthal et al., 2020). The literature cited and discussion made so far in this chapter reveals that agriculture in Pakistan is facing several issues such as low availability of water, low productivity, deprived physical infrastructure, food insecurity, degradation of natural resources (land, water), outdated cultivation methods, issues with supply of agricultural inputs and lack of adoption of the latest technology coupled with climate change threats. This situation calls for sound decision and policy making at national and provincial levels. For evidence-based decision and policy making, spatial data is an indispensable element. But finding the 30 spatial datasets (see Table 6) that are consistent and compatible is problematic(Ackrill, 2000, p.80). The timely availability of spatial information can impact directly and positively agricultural policymaking. From an agricultural policy perspective, governments have to prioritize resource mobilization such as seeds, fertilizers and pesticides in the first place. In the second place, establishment of physical infrastructures such as transportation, water and food storage infrastructure should be setup in order to overcome postharvest losses. For resource mobilization, developing physical infrastructures and studying the impact of agricultural policy (Scozzafava, 2008) access to spatial data of various types is a pre-condition. In this background, the study proposes the establishment of spatial data infrastructure (SDI) as the means to assemble and share geographic information held by various organizations for effective and evidence-based policy making including but not limited to agriculture.

\section{References}

Abbas, G., Ahmad, S., Ahmad, A., Nasim, W., Fatima, Z., Hussain, S., Rehman, M. H. ur, Khan, M. A., Hasanuzzaman, M., Fahad, S., Boote, K. J., \& Hoogenboom, G. (2017). Quantification the impacts of climate change and crop management on phenology of maize-based cropping system in Punjab, Pakistan. Agricultural and Forest Meteorology, 247, 42-55. https://doi.org/10.1016/j.agrformet.2017.07.012

Abbas, M., Nadeem, A. M., Hassan, B., Rafique, M. Z., \& Huang, S. (2016). A study on historical development of landownership and landed aristocracy in Pakistan. Pacific Rim Property Research Journal, 22(3), 217-230. https://doi.org/10.1080/14445921.2016.1235756

Abdelrahman, M. A. E., Natarajan, A., \& Hegde, R. (2016). Assessment of land suitability and capability by integrating remote sensing and GIS for agriculture in Chamarajanagar district, Karnataka, India. Egyptian Journal of Remote Sensing and Space Science, 19(1), 125-141. https://doi.org/10.1016/j.ejrs.2016.02.001 
Ackrill, R. (2000). Common Agricultural Policy. Bloomsbury Publishing.

ADB. (2009). Building Climate Resilience in the Agriculture Sector of Asia and the Pacific. Asian Development

Bank. http://www.adb.org/sites/default/files/publication/27531/building-climate-resilienceagriculture-sector.pdf\%5Cnpapers3://publication/uuid/E4E58E2F-3858-471B-A0AC810C59DFC0C3

Ahmad, M. and I., Farooq, M. and, \& Umar. (2016). Food Security and its Constraining Factors in South Asia: Challenges and Opportunities. In Munich Personal RePEc Archive (Issue 72868). https://mpra.ub.uni-muenchen.de/id/eprint/72868

Ahmad, M., \& Farooq, U. (2010). The state of food security in Pakistan: Future challenges and coping strategies. The Pakistan Development Review, 903-923.

Ahmad, M., Mustafa, G., \& Iqbal, M. (2016). Impact of farm households' adaptations to climate change on food security: Evidence from different agro-ecologies of Pakistan. In Pakistan Development Review (Vol. 55, Issue 4, pp. 561-588). Pakistan Institute of Development Economics, Islamabad. https://doi.org/10.30541/v55i4i-iipp.561-588

Akram, M., Alam, H. M., \& Iqbal, Z. (2018). Impact of Financing on Production with Mediating Role of Rural Population: Evidence from Agricultural Sector of Pakistan. Journal of the Research Society of Pakistan-Vol, 55(2).

Ali, A., \& Erenstein, O. (2017). Assessing farmer use of climate change adaptation practices and impacts on food security and poverty in Pakistan. Climate Risk Management, 16, 183-194. https://doi.org/10.1016/j.crm.2016.12.001

Ali Chandio, A., Jiang, Y., Ali Joyo, M., \& Rehman, A. (2016). Impact of Area under Cultivation, Water Availability, Credit Disbursement, and Fertilizer Off-take on Wheat Production in Pakistan. J. Appl. Environ. Biol. Sci, 6(10), 10-18. https://www.researchgate.net/publication/309735720

Ali $^{1}$, A., \& Ahmad, M. (2012). Is SDI Development, Waste of Time and Money for Pakistan?

Aslam, M., \& Prathapar, S. A. (2006). Strategies to mitigate secondary salinization in the Indus Basin of Pakistan: a selective review. In IWMI Research Report 097. https://doi.org/10.3910/2009.097

Atzberger, C. (2013). Advances in remote sensing of agriculture: Context description, existing operational monitoring systems and major information needs. In Remote Sensing (Vol. 5, Issue 2, pp. 949-981). https://doi.org/10.3390/rs5020949

Awan, A. G., \& Yaseen, G. (2017). Global Climate Change and Its Impact on Agriculture Sector in Pakistan. American Journal of Trade and Policy, 4(1), 41-48.

Azam, A., \& Shafique, M. (2017). Agriculture in Pakistan and its Impact on Economy-A.

Bai, W., Sun, Z., Zheng, J., Du, G., Feng, L., Cai, Q., Yang, N., Feng, C., Zhang, Z., Evers, J. B., van der Werf, W., \& Zhang, L. (2016). Mixing trees and crops increases land and water use efficiencies in a semi-arid area. Agricultural Water Management, 178, 281290. https://doi.org/10.1016/j.agwat.2016.10.007

Barjolle, D., Sylvander, B., \& Thévenod-Mottet, E. (2011). Public policies and geographical indications. In Labels of Origin for Food: Local Development, Global Recognition (pp. 92-105). https://doi.org/10.1079/9781845933524.0092

Basnett, Y., \& Bhattacharya, D. (2015). Exploring spaces for economic transformation in Sustainable Development Goals. In odi.org (Issue May). http://www.odi.org/sites/odi.org.uk/files/odi-assets/publications-opinionfiles/9651.pdf

Baumgartner, F. R., \& Jones, B. D. (2015). The Politics of Information: Problem Definition and the Course of Public Policy in America. University of Chicago Press. https://books.google.com.pk/books?id=FdsUBQAAQBAJ

Below, T. B., Schmid, J. C., \& Sieber, S. (2015). Farmers' knowledge and perception of 
climatic risks and options for climate change adaptation: a case study from two Tanzanian villages. Regional Environmental Change, 15(7), 1169-1180. https://doi.org/10.1007/s10113-014-0620-1

Birthal, P. S., Hazrana, J., \& Negi, D. S. (2020). Diversification in Indian agriculture towards high value crops: Multilevel determinants and policy implications. Land Use Policy, 91, 104427. https://doi.org/10.1016/j.landusepol.2019.104427

Bordogna, G., Kliment, T., Frigerio, L., Brivio, P. A., Crema, A., Stroppiana, D., Boschetti, M., \& Sterlacchini, S. (2016). A spatial data infrastructure integrating multisource heterogeneous geospatial data and time series: A study case in agriculture. ISPRS International Journal of Geo-Information, 5(5), 73. https://doi.org/10.3390/ijgi5050073

Boron, V., Payán, E., MacMillan, D., \& Tzanopoulos, J. (2016). Achieving sustainable development in rural areas in Colombia: Future scenarios for biodiversity conservation under land use change. Land Use Policy, 59, 27-37. https://doi.org/10.1016/j.landusepol.2016.08.017

Byerlee, D., de Janvry, A., \& Sadoulet, E. (2009). Agriculture for Development: Toward a New Paradigm. Annual Review of Resource Economics, 1(1), 15-31. https://doi.org/10.1146/annurev.resource.050708.144239

CCAFS. (2016). Annual Report 2015: Change for the better|CCAFS: CGIAR research program on Climate Change, Agriculture and Food Security. https://ccafs.cgiar.org/fr/node/53395

Cervantes-Godoy, D., Brooks, J., Cervantes-Godoy, D., \& Brooks, J. (2008). Smallholder Adjustment in Middle-Income Countries ISSUES AND POLICY RESPONSES. https://doi.org/10.1787/228583166164

Chakhar, S., \& Mousseau, V. (2008). GIS-based multicriteria spatial modeling generic framework. International Journal of Geographical Information Science, 22(11-12), 1159-1196. https://doi.org/10.1080/13658810801949827

Chandio, N., Anwar, M., \& Chandio, A. (2011). Degradation of Indus delta, Removal mangroves forestland Its Causes: A Case study of Indus River delta. Sindh University Research Journal-SURJ (Science Series), 43(1), 67-72. http://sujo.usindh.edu.pk/index.php/SURJ/article/view/1306

Chantillon, M., Crompvoets, J., \& Peristeras, V. (2017). The governance landscape of geospatial E-services - The Belgian case. ISPRS International Journal of GeoInformation, 6(9). https://doi.org/10.3390/ijgi6090282

Chegere, M. J. (2019). Climate change and post-harvest agriculture. Agricultural Adaptation to Climate Change in Africa, 283-294. https://doi.org/10.4324/9781315149776-12

Chougule, A., Jha, V. K., \& Mukhopadhyay, D. (2016). Agrokanti: Location-aware decision support system for forecasting of pests and diseases in grapes. Advances in Intelligent Systems and Computing, 433, 677-685. https://doi.org/10.1007/978-81-322-27557_70

Christiaensen, L., Demery, L., \& Kuhl, J. (2011). The (evolving) role of agriculture in poverty reduction-An empirical perspective. Journal of Development Economics, 96(2), 239254. https://doi.org/10.1016/J.JDEVECO.2010.10.006

Christiaensen, L., \& Martin, W. (2018). Agriculture, structural transformation and poverty reduction: Eight new insights. In World Development (Vol. 109, pp. 413-416). Elsevier Ltd. https://doi.org/10.1016/j.worlddev.2018.05.027

Coppock, J. T. (1974). Geography and Public Policy: Challenges, Opportunities and Implications. Transactions of the Institute of British Geographers, 63, 1. https://doi.org/10.2307/621525

de Vries, W. T., \& Asmat, A. (2016). The Theory versus the Reality of Alignment between EGov and SDI in Pakistan. In Spatial Enablement in a Smart World (pp. 111-131). 
GSDI Association Press.

Dinar, A. (1993). Economic factors and opportunities as determinants of water use efficiency in agriculture. Irrigation Science, 14(2), 47-52. https://doi.org/10.1007/BF00208397

Dizon, F., Josephson, A., \& Raju, D. (2019). The Nutrition Sensitivity of Food and Agriculture in South Asia (Policy Research Working Papers, Issue March). The World Bank. https://doi.org/10.1596/1813-9450-8766

Donoghue, D., \& Khan, A. (2019). Achieving the SDGs and "leaving no one behind" Maximising synergies and mitigating trade-offs. In ODI Working Paper 560 (Issue September). $\quad$ https://apo.org.au/sites/default/files/resource-files/2019/07/aponid248116-1373616.pdf

Dorosh, P., Malik, S. J., \& Krausova, M. (2010). Rehabilitating agriculture and promoting food security after the 2010 Pakistan floods: Insights from the south Asian experience. In Pakistan Development Review (Vol. 49, Issue 3, pp. 167-192). Pakistan Institute of Development Economics, Islamabad. https://doi.org/10.30541/v49i3pp.167-192

Duncombe, R. (2018). Digital Technologies for Agricultural and Rural Development in the Global

South.

https://books.google.com/books?hl=en\&lr=\&id=gQJbDwAAQBAJ\&oi=fnd\&pg=PR1 $\& \mathrm{dq}=$ Digital+Technologies+for+Agricultural+and+Rural+Development+in+the+Glob al+South\&ots=8VMPDSGexy\&sig=mEoiBngW6SVTye8Hw07FjgfevE0

Edeme, R. K., Nkalu, N. C., Idenyi, J. C., \& Arazu, W. O. (2020). Infrastructural Development, Sustainable Agricultural Output and Employment in ECOWAS Countries. Sustainable Futures, 100010. https://doi.org/10.1016/j.sftr.2020.100010

Elahi, E., Khalid, Z., Weijun, C., \& Zhang, H. (2020). The public policy of agricultural land allotment to agrarians and its impact on crop productivity in Punjab province of $\begin{array}{llll}\text { Pakistan. Land Use Policy, } & \text { 90, }\end{array}$ https://doi.org/10.1016/j.landusepol.2019.104324

Elahi, E., Zhang, L., Abid, M., Altangerel, O., Bakhsh, K., Uyanga, B., Ahmed, U. I., \& Xinru, H. (2015). Impact of Balance Use of Fertilizers on Wheat Efficiency in Cotton Wheat Cropping System of Pakistan. Ijair, 3(5), 1470-1474. http://ijair.org/index.php?option=com_jresearch\&view=publication\&task=show\&id=4 92

Erb, K. H., Luyssaert, S., Meyfroidt, P., Pongratz, J., Don, A., Kloster, S., Kuemmerle, T., Fetzel, T., Fuchs, R., Herold, M., Haberl, H., Jones, C. D., Marín-Spiotta, E., McCallum, I., Robertson, E., Seufert, V., Fritz, S., Valade, A., Wiltshire, A., \& Dolman, A. J. (2017). Land management: data availability and process understanding for global change studies. In Global Change Biology (Vol. 23, Issue 2, pp. 512-533). https://doi.org/10.1111/gcb.13443

Coordinating geographic data acquisition and access, the National Spatial Data Infrastructure, Executive Order 12906, Federal Register 59,17671-17674, 591 (1994) (testimony of 1994 Executive Office of the President). https://ci.nii.ac.jp/naid/10003378350/

FAO. (2014a). FAO success stories on climate-smart agriculture. In FAO.

FAO. (2014b). Food and Nutrition in Numbers 2014. FAO. http://www.fao.org/publications/card/en

FAO. (2019). No Title. In Agriculture and climate change - Challenges and opportunities at the global and local Level - Collaboration on Climate-Smart Agriculture (p. 52). http://www.fao.org/3/CA3204EN/ca3204en.pdf

Fatima, I. N. N. S. B., \& Yousaf, I. K. A. (2014). Food security situation of small farmers in district Rawalpindi. International Journal of Advanced Research in Biological Sciences, 205-211. https://www.ijarbs.com/pdfcopy/nov2014/ijarbs21.pdf 
Fonseca, F., Davis, C., \& Câmara, G. (2003). Bridging ontologies and conceptual schemas in geographic information integration. GeoInformatica, 7(4), 355-378. https://doi.org/10.1023/A:1025573406389

Fritz, S., See, L., Bayas, J. C. L., Waldner, F., Jacques, D., Becker-Reshef, I., Whitcraft, A., Baruth, B., Bonifacio, R., Crutchfield, J., Rembold, F., Rojas, O., Schucknecht, A., Van der Velde, M., Verdin, J., Wu, B., Yan, N., You, L., Gilliams, S., .. McCallum, I. (2019). A comparison of global agricultural monitoring systems and current gaps. Agricultural Systems, 168, 258-272. https://doi.org/10.1016/j.agsy.2018.05.010

Gahukar, R. T. (2011). Food Security in India: The Challenge of Food Production and Distribution. Journal of Agricultural and Food Information, 12(3-4), 270-286. https://doi.org/10.1080/10496505.2011.588932

Gardner, B. L. (1978). Public Policy and the Control of Agricultural Production. American Journal of Agricultural Economics, 60(5), 836. https://doi.org/10.2307/1240103

Ghazal, L., Kazmi, J. H., \& Zubair, S. (2015). Monitoring and Mapping Spatio-Periodic Dynamics of Vegetation Cover in Karachi Using Geoinformatics. In Article in International Journal of Biology and Biotechnology (Vol. 12, Issue 4). https://www.researchgate.net/publication/300065451

Ghosh, M. (2019). Climate-smart Agriculture, Productivity and Food Security in India. Journal of Development Policy and Practice, 4(2), 166-187. https://doi.org/10.1177/2455133319862404

Government of Khyber Pakhtunkhwa. (2017). Agriculture Policy Khyber Pakhtunkhwa A Ten Year Perspective. http://extwprlegs1.fao.org/docs/pdf/pak173417.pdf

Government of Pakistan. (2012). National Climate Change Policy 2012. Ministry of Climate Change. http://www.mocc.gov.pk/policiesDetails.aspx

Government of Pakistan. (2014). Pakistan Vision 2025. Ministry of Planning Development \& Special Initiatives. https://www.pc.gov.pk/

Government of Pakistan. (2016). Pakistan Economic Survey 2015-16. Ministry of Finance. http://www.finance.gov.pk

Government of Pakistan. (2018a). Digital Pakistan Policy (p. 24). Ministry of Information and

Broadcasting.

http://moib.gov.pk/Downloads/Policy/DIGITAL_PAKISTAN_POLICY(22-052018).pdf

Government of Pakistan. (2018b). Economic Survey of Pakistan 2017-18. Ministry of Finance. http://www.finance.gov.pk

Government of Pakistan. (2018c). National Food Security Policy. Ministry of National Food Security \& Research. http://www.mnfsr.gov.pk/policiesDetails.aspx

Government of Pakistan. (2018d). National Water Policy 2018 (p. 52). Ministry of Water Resources. http://mowr.gov.pk/index.php/national-water-policy-2018/

Government of Pakistan. (2019a). Annual Plan 2019-20 (pp. 45-50). Ministry of Planning Development \& Special Initiatives. https://www.pc.gov.pk/

Government of Pakistan. (2019b). Pakistan Economic Survey 2018-19. Ministry of Finance. https://doi.org/10.1038/479299e

Government of Pakistan. (2020). Pakistan Statistical Year Book 2018 (Provisional ) (p. 539). Pakistan Bureau of Statistics. http://www.pbs.gov.pk/

Government of Pakistan, G. (2005). National Environment Policy. Ministry of Climate Change. http://mowr.gov.pk/index.php/polices/

Government of Pakistan, G. (2015). Pakistan Economic Survey 2014-15. Ministry of Finance. http://www.finance.gov.pk

Government of Punjab. (2018). Punjab Agriculture Policy 2018 (p. 58). Provincial Government of Punjab. http://www.agripunjab.gov.pk

Government of Sindh. (2018). Sindh Agriculture Policy (2018-2030) (p. 38). Provincial 
Government of Sindh. http://www.wsip.com.pk

Greer, R., \& Jagirdar, S. A. H. (2006). Evaluation of the Agriculture and Natural Resources Management Sector. https://www.adb.org/sites/default/files/evaluationdocument/35930/files/agriculture-management-pak.pdf

Han, W., Yang, Z., Di, L., Member, S., Zhang, B., \& Peng, C. (2014). Enhancing Agricultural Geospatial Data Dissemination and Applications Using Geospatial Web Services. Ieeexplore.Ieee.Org. https://doi.org/10.1109/JSTARS.2014.2315593

Harris, N., \& Hooper, A. (2004). Rediscovering the "spatial" in public policy and planning: An examination of the spatial content of sectoral policy documents. In Planning Theory and Practice (Vol. 5, Issue 2, pp. 147-169). Taylor and Francis Ltd. https://doi.org/10.1080/14649350410001691736

Headey, D., Chiu, A., \& Kadiyala, S. (2012). Agriculture's role in the Indian enigma: Help or hindrance to the crisis of undernutrition? Food Security, 4(1), 87-102. https://doi.org/10.1007/s12571-011-0161-0

Headey, D. D., \& Hoddinott, J. (2016). Agriculture, nutrition and the green revolution in $\begin{array}{llll}\text { Bangladesh. Agricultural } & \text { Systems, } & 149, & 122-131 .\end{array}$ https://doi.org/10.1016/j.agsy.2016.09.001

Hinkel, J. (2011). “Indicators of vulnerability and adaptive capacity”: Towards a clarification of the science-policy interface. Global Environmental Change, 21(1), 198-208. https://doi.org/10.1016/j.gloenvcha.2010.08.002

Honda, K., Ines, A. V. M., Yui, A., Witayangkurn, A., Chinnachodteeranun, R., \& Teeravech, K. (2014). Agriculture information service built on geospatial data infrastructure and crop modeling. ACM International Conference Proceeding Series. https://doi.org/10.1145/2637064.2637094

Huang, Y., CHEN, Z. xin, YU, T., HUANG, X. zhi, \& GU, X. fa. (2018). Agricultural remote sensing big data: Management and applications. In Journal of Integrative Agriculture (Vol. 17, Issue 9, pp. 1915-1931). Chinese Academy of Agricultural Sciences. https://doi.org/10.1016/S2095-3119(17)61859-8

Huang, Y. Q., Cui, W. H., Zhang, Y. J., \& Deng, G. Y. (2012). Research on Development of Agricultural Geographic Information Ontology. Journal of Integrative Agriculture, 11(5), 865-877. https://doi.org/10.1016/S2095-3119(12)60077-X

Husain, I. (2001). Impact of globalization on poverty in Pakistan. Mahbubul Haq Human Development Review, 1(1), 24.

Husain, I. (2013, November 14). Formulating public policy. https://www.dawn.com/news/1056309

Hussain, A., Rasul, G., Mahapatra, B., \& Tuladhar, S. (2016). Household food security in the face of climate change in the Hindu-Kush Himalayan region. Food Security, 8(5), 921-937. https://doi.org/10.1007/s12571-016-0607-5

Hussain, I. (2008). Public policy and social sciences. A Paper.

Imran, M. (2013). A spatial statistical study on upscaling in the SDI framework: the case of yield and poverty in Burkina Faso.

INSPIRE. (2013). Data Specification on Agricultural and Aquaculture Facilities - Technical Guidelines.

Irshad, M., Inoue, M., Ashraf, M., Faridullah, Delower, H. K. M., \& Tsunekawa, A. (2007). Land desertification - An emerging threat to environment and food security of Pakistan. Journal of Applied Sciences, 7(8), 1199-1205. https://doi.org/10.3923/jas.2007.1199.1205

Islam, N. (2001). Democracy and governance in Pakistan's fragmented society. International Journal of Public Administration, 24(12), 1335-1355.

Jabeen, N., Jadoon, Z. I., \& Salman, Y. (2016). Revisiting Public Policy Making Process and 
Strategies in Pakistan: A Governance Perspective. South Asian Studies, 31(2), 17.

Jasinski, E., Morton, D., DeFries, R., Shimabukuro, Y., Anderson, L., \& Hansen, M. (2005). Physical landscape correlates of the expansion of mechanized agriculture in Mato Grosso, Brazil. Earth Interactions, 9(16). https://doi.org/10.1175/EI143.1

Jehangir, W. A., Masih, I., \& Ahmed, S. (2007). Sustaining Crop Water Productivity in RiceWheat Systems of South Asia: A Case Study from the. https://books.google.com/books?hl=en\&lr=\&id=yz8L0npW-

mAC\&oi=fnd\&pg=PR4\&ots=IRv7WIN_2a\&sig=W_mtLk8okG7eutKHLVJMb9OCp UQ

Jiang, G., Zhang, R., Ma, W., Zhou, D., Wang, X., \& He, X. (2017). Cultivated land productivity potential improvement in land consolidation schemes in Shenyang, China: assessment and policy implications. Land Use Policy, 68, 80-88. https://doi.org/10.1016/j.landusepol.2017.07.001

Justice, C. O., Townshend, J. R. G., Vermote, E. F., Masuoka, E., Wolfe, R. E., Saleous, N., Roy, D. P., \& Morisette, J. T. (2002). An overview of MODIS Land data processing and product status. Remote Sensing of Environment, 83(1-2), 3-15. https://doi.org/10.1016/S0034-4257(02)00084-6

Kamilaris, A., Assumpcio, A., Blasi, A. B., Torrellas, M., \& Prenafeta-Boldú, F. X. (2018). Estimating the Environmental Impact of Agriculture by Means of Geospatial and Big Data Analysis: The Case of Catalonia (pp. 39-48). Springer, Cham. https://doi.org/10.1007/978-3-319-65687-8_4

Khalid, I., Mushtaq, M., \& Naveed, A. (2016). Loopholes in Public Policy Making: A Case Study of Pakistan. Journal of Political Studies, 23(2).

Khan, I., \& Khan, M. (2018). Developing Sustainable Agriculture in Pakistan. In Developing Sustainable Agriculture in Pakistan. CRC Press. https://doi.org/10.1201/9781351208239

Khan, M. H., \& Imam, S. F. (1985). Public Policy and Agricultural Transformation in Pakistan. In The Pakistan Development Review (Vol. 24, pp. 305-332). Pakistan Institute of Development Economics, Islamabad. https://doi.org/10.2307/41258714

Khan, M. R. (2011). Crops from space: improved earth observation capacity to map crop areas and to quantify production. In $P h$ D. Thesis (Vol. 1). https://research.utwente.nl/en/publications/crops-from-space-improved-earthobservation-capacity-to-map-crop-

Kirk, A., Kilic, T., \& Carletto, C. (2018). Composition of Household Income and Child Nutrition Outcomes Evidence from Uganda. World Development, 109, 452-469. https://doi.org/10.1016/j.worlddev.2017.03.023

Kliment, T., Bordogna, G., Frigerio, L., Crema, A., Boschetti, M., Brivio, P. A., \& Sterlacchini, S. (2015). Image data and metadata workflows automation in geospatial data infrastructure deployed for agricultural sector. International Geoscience and Remote Sensing Symposium (IGARSS), 2015-Novem, 146-149. https://doi.org/10.1109/IGARSS.2015.7325720

Kolady, D., Srivastava, S., \& Singh, J. (2016). Can agricultural growth explain the reversal of a declining trend in per capita calorie consumption in India? In 2016 Annual Meeting,. http://ageconsearch.umn.edu/bitstream/235862/2/Calorie consumption debate_kolady_Srivastava_Singh.pdf

Korduan, P., Bill, R., \& Bölling, S. (2004). An Interoperable Geodata Infrastructure for Precision Agriculture. 7th AGILE Conference on Geographic Information Science, 747-751.

http://citeseerx.ist.psu.edu/viewdoc/download?doi=10.1.1.497.7725\&rep=rep1\&type= pdf

Lal, R. (2018). Managing agricultural soils of Pakistan for food and climate. Soil and 
Environment, 37(1), 1-10. https://doi.org/10.25252/SE/18/61527

LeGouis, J., Oury, F.-X., \& Charmet, G. (2020). How changes in climate and agricultural practices influenced wheat production in Western Europe. Journal of Cereal Science, 93, 102960. https://doi.org/10.1016/j.jcs.2020.102960

Li, T., Long, H., Zhang, Y., Tu, S., Ge, D., Li, Y., \& Hu, B. (2017). Analysis of the spatial mismatch of grain production and farmland resources in China based on the potential crop rotation system. Land Use Policy, 60, 26-36. https://doi.org/10.1016/j.landusepol.2016.10.013

Ligon, E., \& Sadoulet, E. (2018). Estimating the Relative Benefits of Agricultural Growth on the Distribution of Expenditures. In World Development (Vol. 109). https://doi.org/10.1016/j.worlddev.2016.12.007

Liu, S. L., Pu, C., Ren, Y. X., Zhao, X. L., Zhao, X., Chen, F., Xiao, X. P., \& Zhang, H. L. (2016). Yield variation of double-rice in response to climate change in Southern China. European Journal of Agronomy, 81, 161-168. https://doi.org/10.1016/j.eja.2016.09.014

Liu, Y., Amin, A., Rasool, S. F., \& Zaman, Q. U. (2020). The role of agriculture and foreign remittances in mitigating rural poverty: Empirical evidence from Pakistan. Risk Management and Healthcare Policy, 13, 13-26. https://doi.org/10.2147/RMHP.S235580

Lucà, F., Buttafuoco, G., \& Terranova, O. (2018). GIS and Soil. In Comprehensive Geographic Information Systems (Vol. 3, pp. 37-50). Elsevier Inc. https://doi.org/10.1016/B978-0-12-409548-9.09634-2

M, U. (2016). Contribution of Agriculture Sector in the GDP Growth Rate of Pakistan. Journal of Global Economics, 4(2). https://doi.org/10.4172/2375-4389.1000184

Macheridis, N. (2015). Coordination between governance actors in universities: the role of policy documents. Tertiary Education and Management, 21(3), 173-185. https://doi.org/10.1080/13583883.2015.1031273

Majeed, Z. A., \& Hanafiah, F. A. B. U. (2018). SDI approach in the increased use of GIS in government (Issue

January). https://www.researchgate.net/profile/Zainal_A_Majeed/publication/322418162_SDI_ APPROACH_IN_THE_INCREASED_USE_OF_GIS_IN_GOVERNMENT/links/5a5 81a40aca2726376b715d8/SDI-APPROACH-IN-THE-INCREASED-USE-OF-GISIN-GOVERNMENT.pdf

Malczewski, J. (1999). GIS and Multicriteria Decision Analysis. John Wiley \& Sons, Inc., USA.

Malczewski, J., \& Rinner, C. (2015). Multicriteria Decision Analysis in Geographic Information Science. Analysis Methods, Massam 1993, 331. https://doi.org/10.1007/978-3-540-74757-4

Malik, S. J., Sheikh, A. T., \& Jilani, A. H. (2016). Inclusive Agricultural Growth in Pakistan-Understanding Some Basic Constraints. The Pakistan Development Review, 55(4 Part I \&), 889-903.

Mann, M. E., Rahmstorf, S., Kornhuber, K., Steinman, B. A., Miller, S. K., \& Coumou, D. (2017). Influence of Anthropogenic Climate Change on Planetary Wave Resonance and Extreme Weather Events. Scientific Reports, 7(1), 1-12. https://doi.org/10.1038/srep45242

Masser, I. (2007). National spatial data infrastructure phenomenon. In GIS and EvidenceBased Policy Making (pp. 3-18). https://doi.org/10.1201/9781420008234.pt1

Mihai, Florin \& Latu, C. (2020). Sustainable Rural Development under Agenda 2030 | IntechOpen. In intechopen.com. https://www.intechopen.com/online-first/prologuesustainable-rural-development-under-agenda-2030 
Monmonier, M. S. (1982). Cartography, geographic information, and public policy. Journal of Geography in Higher Education, 6(2), 99-107. https://doi.org/10.1080/03098268208708847

Moro, L. (2016). FAO Uses GIS to Protect Agricultural Economy of Vulnerable Countries GIS Lounge. https://www.gislounge.com/fa-uses-gis-protect-agricultural/

Morton, J. F. (2007). The impact of climate change on smallholder and subsistence agriculture. Proceedings of the National Academy of Sciences of the United States of America, 104(50), 19680-19685. https://doi.org/10.1073/pnas.0701855104

Nash, E., Korduan, P., \& Bill, R. (2009). Applications of Open Geospatial web services in precision agriculture: A review. Precision Agriculture, 10(6), 546-560. https://doi.org/10.1007/s11119-009-9134-0

National Research Council. (1993). Toward a Coordinated Spatial Data Infrastructure for the Nation. In Toward a Coordinated Spatial Data Infrastructure for the Nation. https://doi.org/10.17226/2105

Neylon, C. (2017). Building a Culture of Data Sharing: Policy Design and Implementation for Research Data Management in Development Research. Research Ideas and Outcomes, 3, 21773. https://doi.org/10.3897/rio.3.e21773

NIAB. (1997). Economic utilization of salt-affected soils In Twenty Five Years (1992-1997) of NIAB (Silver Jubilee Publication). (pp. 123-151). Nuclear Institute for Agriculture and Biology, Faisalabad, Pakistan.

Norton, G. W. (2016). Hertel, Thomas W. and Uris Lantz C. Baldos. Global Change and the Challenges of Sustainably Feeding a Growing Planet. American Journal of Agricultural Economics, 98(5), 1558-1560. https://doi.org/10.1093/ajae/aaw013

OECD/FAO. (2016). OECD-FAO Agricultural Outlook 2016-2025. In OECD Publishing. OECD Publishing. https://doi.org/10.1787/agr_outlook-2016-en

OECD. (2010). Agricultural Policies in OECD Countries 2010. https://doi.org/doi:https://doi.org/10.1787/agr_oecd-2010-en

OECD. (2015). OECD Review of Agricultural Policies: Colombia 2015. In La Organización para la Cooperación y el Desarrollo Económico. OECD. https://doi.org/http://dx.doi.org/10.1787/9789264227644-en

OECD. (2017). OECD Economic Surveys: India 2017. https://doi.org/doi:https://doi.org/10.1787/eco_surveys-ind-2017-en

OECD, \& Brooks, J. (2012). Agricultural Policies for Poverty Reduction. In Agricultural Policies For Poverty Reduction. https://doi.org/doi:https://doi.org/10.1787/9789264112902-en

Padilla-Pérez, R., \& Gaudin, Y. (2014). Science, technology and innovation policies in small and developing economies: The case of Central America. Research Policy, 43(4), 749-759. https://doi.org/10.1016/j.respol.2013.10.011

Paudyal, Dev Raj and McDougall, Kevin and Apan, A. (2011). Spatial data infrastructure convergence: building spatial data infrastructure bridges to address climate change. In Geoinformatics for climate change studies (pp. 377-392). Teri Press, New Delhi, India. https://eprints.usq.edu.au/18751/

Peerzado, M. B., Magsi, H., \& Sheikh, M. J. (2019). Land use conflicts and urban sprawl: Conversion of agriculture lands into urbanization in Hyderabad, Pakistan. Journal of the Saudi Society of Agricultural Sciences, 18(4), 423-428. https://doi.org/10.1016/j.jssas.2018.02.002

Piedra-Bonilla, E. B., da Cunha, D. A., \& Braga, M. J. (2020). Climate variability and crop diversification in Brazil: An ordered probit analysis. Journal of Cleaner Production, 256, 120252. https://doi.org/10.1016/j.jclepro.2020.120252

Ponce, C. (2020). Intra-seasonal climate variability and crop diversification strategies in the Peruvian Andes: A word of caution on the sustainability of adaptation to climate 
$\begin{array}{llll}\text { change. World } & \text { Development, } & 127, & 104740 .\end{array}$ https://doi.org/10.1016/j.worlddev.2019.104740

Prăvălie, R. (2016). Drylands extent and environmental issues. A global approach. In EarthScience Reviews (Vol. 161, pp. 259-278). Elsevier B.V. https://doi.org/10.1016/j.earscirev.2016.08.003

Raja, S. H. (2015). Pakistan's Agricultural Sector:Challenges and Response. https://www.linkedin.com/pulse/pakistans-agricultural-sectorchallenges-responseshahid-hussain-raja

Rasul, G., Mahmood, a, Sadiq, a, \& Khan, S. I. (2012). Vulnerability of the Indus Delta to Climate Change in Pakistan. In Pakistan Journal of Meteorology (Vol. 8, Issue 16). https://pdfs.semanticscholar.org/b729/9e4f4c0038d3bd39fe82578d709762a26019.pdf

Rehman, A., Chandio, A. A., Hussain, I., \& Jingdong, L. (2019). Fertilizer consumption, water availability and credit distribution: Major factors affecting agricultural productivity in Pakistan. Journal of the Saudi Society of Agricultural Sciences, 18(3), 269-274. https://doi.org/10.1016/j.jssas.2017.08.002

Reidsma, P., Ewert, F., Lansink, A. O., \& Leemans, R. (2010). Adaptation to climate change and climate variability in European agriculture: The importance of farm level responses. European Journal of Agronomy, 32(1), 91-102. https://doi.org/10.1016/j.eja.2009.06.003

Saeed, A. (2013). Understanding Policy Making and Implementation in Pakistan: A Case of Hospital Autonomy Reforms. Pub Pol Admin Res, 3, 23-32.

Sakai, T., \& Chikatsu, H. (2008). Visualization of road slope aspect for fixed property appraisal of lands using DEM. ISPRS Commission II, WG II /5, XXXVII, 655-658. http://citeseerX.ist.psu.edu/viewdoc/download?doi=10.1.1.150.9550\&rep=rep1\&type= pdf

Scozzafava, G. (2008). Proposal For A Territorial Assessment Of The Effects Of Agricultural Policies With A Georeferred Mathematical Programming Model: A Case Study. 109th Seminar, November 20-21, 2008, Viterbo, Italy. http://ideas.repec.org/p/ags/eaa109/44864.html

Sharma, R., Kamble, S. S., \& Gunasekaran, A. (2018). Big GIS analytics framework for agriculture supply chains: A literature review identifying the current trends and future perspectives. In Computers and Electronics in Agriculture (Vol. 155, pp. 103-120). Elsevier B.V. https://doi.org/10.1016/j.compag.2018.10.001

Shirgure, P., \& Shirgure, P. S. (2013). Research review on Irrigation scheduling and water requirement in citrus Precision citriculture through enhanced water-and nutrient-useefficiency in Nagpur mandarin (Citrus reticulata Blanco).. View project Development of Integrated Nutrient Management M. P.S. Shirgure / Scientific Journal of Review, 2(4), 113-121. www.Sjournals.com

Shukla, P. R., Skea, J., Calvo Buendia, E., Masson-Delmotte, V., Pörtner, H.-O., Roberts, D. C., Zhai, P., Slade, R., Connors, S., \& van Diemen, R. (2019). Climate Change and Land: an IPCC special report on climate change, desertification, land degradation, sustainable land management,foodsecurity, and greenhouse gas fluxes in terrestrial ecosystems. In Ipcc. https://doi.org/10.4337/9781784710644

Sial, A. (2011). Sovereignty of People-Pakistan: A Case Study. South Asian Studies, 26(1), 117-130.

Simukanga, A., Muhone, M. P., Mulenga, J., Phiri, J., \& Nyirenda, M. (2018). Creation of an Agricultural Geographical Information System. Zambia ICT Journal, 2(2), 8. https://doi.org/10.33260/zictjournal.v2i2.57

Sirajul, H. A. Q. (2015). Public policy process in Pakistan: Key causes of public policies failures. Journal of Economic and Social Thought, 2(2), 127-131. 
Spielman, D. J., Malik, S. J., Dorosh, P., \& Ahmad, N. (2016). Agriculture and the Rural Economy in Pakistan: Issues, Outlooks, and Policy Priorities. University of Pennsylvania Press.

Srivastava, Y. (2019). Climate change: A challenge for postharvest management, food loss, food quality, and food security. In Climate Change and Agricultural Ecosystems: Current Challenges and Adaptation (pp. 355-377). Elsevier. https://doi.org/10.1016/B978-0-12-816483-9.00019-0

Steenwerth, K. L., Hodson, A. K., Bloom, A. J., Carter, M. R., Cattaneo, A., Chartres, C. J., Hatfield, J. L., Henry, K., Hopmans, J. W., Horwath, W. R., Jenkins, B. M., Kebreab, E., Leemans, R., Lipper, L., Lubell, M. N., Msangi, S., Prabhu, R., Reynolds, M. P., Sandoval Solis, S., ... Jackson, L. E. (2014). Climate-smart agriculture global research agenda: Scientific basis for action. Agriculture and Food Security, 3(1). https://doi.org/10.1186/2048-7010-3-11

Tariq, M., Ahmad, S., Fahad, S., Abbas, G., Hussain, S., Fatima, Z., Nasim, W., Mubeen, M., Rehman, M. H. ur, Khan, M. A., Adnan, M., Wilkerson, C. J., \& Hoogenboom, G. (2018). The impact of climate warming and crop management on phenology of sunflower-based cropping systems in Punjab, Pakistan. Agricultural and Forest Meteorology, 256-257, 270-282. https://doi.org/10.1016/j.agrformet.2018.03.015

Tiwari, K. R., Sitaula, B. K., Nyborg, I. L. P., \& Paudel, G. S. (2008). Determinants of farmers' adoption of improved soil conservation technology in a Middle Mountain Watershed of Central Nepal. Environmental Management, 42(2), 210-222. https://doi.org/10.1007/s00267-008-9137-z

Tóth, K., \& Kučas, A. (2016). Spatial information in European agricultural data management. Requirements and interoperability supported by a domain model. Land Use Policy, 57, 64-79. https://doi.org/10.1016/j.landusepol.2016.05.023

Ullah, A., Arshad, M., Kächele, H., Khan, A., Mahmood, N., \& Müller, K. (2020). Information asymmetry, input markets, adoption of innovations and agricultural land use in Khyber Pakhtunkhwa, Pakistan. Land Use Policy, 90, 104261. https://doi.org/10.1016/j.landusepol.2019.104261

Ullah, R., Shivakoti, G. P., Kamran, M. A., \& Zulfiqar, F. (2019). Land Ownership and Catastrophic Risk Management in Agriculture: The Case of Khyber Pakhtunkhwa Province of Pakistan. International Journal of the Commons, 13(2), 881-891. https://doi.org/10.5334/ijc.896

UN. (2020). World Economic Situation and Prospects 2020. UN. https://doi.org/10.18356/ee1a3197-en

United Nations. (2019). The Least Developed Countries Report 2019. UNITED NATIONS.

Vepa, S. S., Umashankar, V., Bhavani, R. V, \& Parasar, R. (2014). Agriculture and Child Under-Nutrition in India : A State Level Analysis (Issue July). www.mse.ac.in

Vincent, K. (2007). Uncertainty in adaptive capacity and the importance of scale. Global Environmental Change, 17(1), 12-24. https://doi.org/10.1016/j.gloenvcha.2006.11.009

Wiesmeier, M., Hübner, R., \& Kögel-Knabner, I. (2015). Stagnating crop yields: An overlooked risk for the carbon balance of agricultural soils? In Science of the Total Environment (Vol. 536, pp. 1045-1051). Elsevier. https://doi.org/10.1016/j.scitotenv.2015.07.064

Wilder, A. (2009). The politics of civil service reform in Pakistan. Journal of International Affairs, 63(1), 19-37.

Worrall, L., \& Bond, D. (1997). Geographical information systems, spatial analysis and public policy: The British experience. International Statistical Review, 65(3), 365379. https://doi.org/10.1111/j.1751-5823.1997.tb00314.x

Wu, T., Li, J., Li, T., Sivakumar, B., Zhang, G., \& Wang, G. (2019). High-efficient extraction 
of drainage networks from digital elevation models constrained by enhanced flow enforcement from known river maps. Geomorphology, 340, 184-201. https://doi.org/10.1016/j.geomorph.2019.04.022

Yang, Y., Wilson, L. T., Wang, J., \& Li, X. (2011). Development of an integrated Cropland and Soil Data Management system for cropping system applications. Computers and Electronics in Agriculture, $\quad 76(1), \quad 105-118$. https://doi.org/10.1016/j.compag.2011.01.012

Yu, B. (2012). From Plot to Plate: Linking Agricultural Productivity and Human Nutrition in Bangladesh. Conference of International Association of Agricultural Economists, 1, 1-35. http://ageconsearch.umn.edu/bitstream/126803/2/YuB.pdf

Zhai, Z., Martínez, J. F., Beltran, V., \& Martínez, N. L. (2020). Decision support systems for agriculture 4.0: Survey and challenges. Computers and Electronics in Agriculture, 170, 105256. https://doi.org/10.1016/j.compag.2020.105256

Zhang, Y., Li, Q., Tu, W., Mai, K., Yao, Y., \& Chen, Y. (2019). Functional urban land use recognition integrating multi-source geospatial data and cross-correlations. Computers, Environment and Urban Systems, 78, 101374. https://doi.org/10.1016/j.compenvurbsys.2019.101374

Zulfiqar, F., \& Thapa, G. B. (2017). Agricultural sustainability assessment at provincial level in Pakistan. Land Use Policy, 68, 492-502. https://doi.org/10.1016/j.landusepol.2017.08.016 